This is the accepted manuscript of the article, which has been published in Journal of Business Ethics. 2018, 152(3), 865-886. https://doi.org/10.1007/s10551-016-3375-4

\title{
THE FRONTSTAGE AND BACKSTAGE OF CORPORATE SUSTAINABILITY REPORTING: EVIDENCE FROM THE ARCTIC NATIONAL WILDLIFE REFUGE BILL
}

\author{
Charles H. Cho (ESSEC Business School, France) \\ Matias Laine* (University of Tampere, Finland) \\ Robin W. Roberts (University of Central Florida, US) \\ Michelle Rodrigue (Université Laval, Canada)
}

“Accepted author manuscript" version (postprint)

Cho C.H., Laine M., Roberts R.W. and Rodrigue M. (2018). "The frontstage and backstage of corporate sustainability reporting: Evidence from the Arctic National Wildlife Refuge Bill”. Journal of Business Ethics, 152(3), 865-886.

Publisher DOI: https://doi.org/10.1007/s10551-016-3375-4

* corresponding author: matias.laine@tuni.fi

\section{Acknowledgments:}

The authors wish to thank Carmen Correa (discussant at the 35th EAA Annual Congress), Bruno Oxibar (discussant at the 32eme AFC Congrès), Leslie Paik, Hyemi Shin, and the participants of the $22^{\text {nd }}$ International Congress on Social and Environmental Accounting Research in Saint Andrews, the 4th GECAMB Conference on Environmental Management and Accounting (Portuguese CSEAR Conference) in Leiria, the 2011 Conference of the American Accounting Association's Public Interest Section Mid-Year Meeting in Chicago, the 32 Congrès de l'Association Francophone de Comptabilité (AFC) in Montpellier, the International Workshop on The Role of Business in Society and the Pursuit of the Common Good at ESSEC Business School in Cergy, the 2012 Alternative Accounts Conference in Quebec City, the 35th European Accounting Association Congress in Ljubljana, the 2016 McMaster Symposium in Hamilton and research workshops and seminars at Seoul National University, Pusan National University, Aston Business School, the University of Ottawa, the Conservatoire National des Arts et Métiers (CNAM), the Université de Nice Sophia Antipolis, the University of Central Florida, the University of Maastricht, Dongguk University, HEC Lausanne, and Yonsei University, HEC Lausanne, Concordia University, KAIST, CEIBS, the Ivey Business School, the Schulich School of Business and the Universite Toulouse 1 Capitole for their valuable comments and feedback. Charles Cho also acknowledges the financial support provided by the Fonds Québécois de la Recherche sur la Société et la Culture (FQRSC), the Social Sciences and Humanities Research Council of Canada (SSHRC), and the ESSEC Research Centre (CERESSEC). Michelle Rodrigue acknowledges the financial support from Université Laval's Programme de soutien à la recherche de la Faculté des sciences de l'administration and the École de comptabilité. 


\title{
THE FRONTSTAGE AND BACKSTAGE OF CORPORATE SUSTAINABILITY REPORTING: EVIDENCE FROM THE ARCTIC NATIONAL WILDLIFE REFUGE BILL
}

\begin{abstract}
While proponents of sustainability reporting believe in its potential to help corporations be accountable and transparent about their social and environmental impacts, there has been growing criticism asserting that such reporting schemes are utilized primarily as impression management tools. Drawing on Erving Goffman's (1959) self-presentation theory and its frontstage/backstage analogy, we contrast the frontstage sustainability discourse of a sample of large U.S. oil and gas firms to their backstage corporate political activities in the context of the passage of the American-Made Energy and Good Jobs Act, also known as the Arctic National Wildlife Refuge (ANWR) Bill. The ANWR Bill was designed to allow oil exploration within the most sensitive environmental areas in the Refuge and this bill was vigorously debated in the United States Congress in 2005 and 2006. Our results suggest that the firms' sustainability discourse on environmental stewardship and responsibility contrasts sharply with their less visible but proactive political strategies targeted to facilitate the passage of the ANWR Bill. This study thus contributes to the social and environmental accounting and accountability literature by highlighting the relevance of Goffman's frontstage/backstage analogy in uncovering and documenting further the deceptive nature of the discourse contained in stand-alone sustainability reports. In addition, it seeks to contribute to the overall understanding of the multifaceted nature of sustainability reporting by placing it in relation to corporate political activities.
\end{abstract}

Keywords: backstage and frontstage; Goffman; impression management; lobbying and political strategies; self-presentation; sustainability reporting. 


\section{THE FRONTSTAGE AND BACKSTAGE OF CORPORATE SUSTAINABILITY REPORTING: EVIDENCE FROM THE ARCTIC NATIONAL WILDLIFE REFUGE BILL}

\section{Introduction}

The recent explosion of corporate sustainability reporting is primarily driven by increasing stakeholder concerns and pressures on organizations (Gray et al., 2014). It has been suggested that sustainability reporting provides substantive information to corporate share- and stakeholders (see Rost and Ehrmann, forthcoming), thereby having the potential to improve transparency and aid stakeholders in their attempts to make sense of corporate social and environmental impacts (Bebbington et al., 2014). Significant criticism also exists, arguing that these disclosures tend to be selective and biased (Aras and Crowther, 2008; Boiral, 2016; Milne and Gray, 2013; Milne et al., 2009), and, thus, do not enhance corporate accountability (Michelon et al., 2015). These disagreements in perspective can be explained partially by the lack of sustainability reporting regulation (Merkl-Davies and Brennan, 2007). Flexibility in reporting enables corporate managers to select the specific pieces of information they want to disclose (Adams, 2004; Boiral, 2013; but see also Unerman and Zappettini, 2014), increasing the potential for corporations to engage in impression management (Criado-Jiménez et al., 2008; MerklDavis and Brennan, 2007; 2011).

Prior studies have investigated potential reasons why corporations engage in sustainability reporting while others do not, as well as the purview and accuracy of report content (e.g., Bozzolan et al., 2015; Clarkson et al., 2008; Dhaliwal et al., 2012; Patten, 1992). Most of these studies were conducted either as event case studies or by examining 
the relation between environmental performance and environmental disclosure, and used qualitative or quantitative methods.

The purpose of this study is to advance our understanding of corporate sustainability by combining both a qualitative and quantitative method of analysis to study the congruence (or lack of congruence) between the content of a corporation's sustainability report and its related political activities. Specifically using Goffman's (1959) self-presentation theory - particularly its frontstage/backstage analogy - and a combination of different research analysis methods, we seek to contrast the frontstage sustainability discourse of a sample of large U.S. oil and gas firms with their backstage corporate political activities in the context of the passage of the American-Made Energy and Good Jobs Act, also known as the Arctic National Wildlife Refuge (ANWR) Bill. The ANWR Bill was a piece of legislation that corporate interests argued would have favored business activities and enhanced the economy since it would have created new jobs by opening up areas of the Arctic National Wildlife Refuge to hydrocarbon exploration. Environmentalist and many in the Alaskan indigenous community argued, on the other hand, that the ANWR Bill would do irreparable harm to their native land and way of life. Responding to recent calls to employ original theoretical lenses and to move away from predominant theories used in social and environmental accounting research (Bebbington and Thomson, 2013; Cho et al., 2015; Unerman and Chapman, 2014), we use ANWR as a setting to illustrate the relevance of the frontstage and backstage concepts for developing our empirical and theoretical understanding of corporate sustainability management and disclosures. 
We qualitatively analyze available stand-alone sustainability report disclosures provided by our sample firms during the 2004-2006 period that is most relevant to the ANWR Bill, and contrast the content of these disclosures with their corresponding corporate lobbying activities using a quantitative political action committee empirical model. As explained in detail later in the paper, our analyses focus on this discrete period for three primary reasons. First, the 2004-2006 period represents the most intense and contentious time period in which the major oil corporations pushed the U.S. Congress to pass legislation to allow drilling in ANWR. Second, the corporate lobbying and political action committee activity during this time period coincides with Congressional voting on a bill that would have allowed drilling and provides us an opportunity to empirically model the association between oil corporations' Congressional campaign support and legislator voting. Third, oil exploration activities are very expensive relative to other U.S domestic drilling efforts. Oil prices were at historic highs during this time period and provided more substantive economic arguments for allowing drilling in ANWR. Our post-2006 analysis confirms that, while political debates continue regarding the potential environmental damage associated with oil exploration undertaken in environmentally sensitive areas, the level of debate over drilling in ANWR subsided significantly when the ANWR Bill failed to become law.

Through our analysis we find that the firms' sustainability discourse on the importance of environmental stewardship and responsibility contrasts sharply with their less visible but deliberate and proactive political actions targeted to facilitate the passage of the ANWR Bill. Such disconnection is even more flagrant given that one specific disclosure theme revolves around biodiversity protection and conservation-a critical 
issue for the Arctic National Wildlife Refuge. Our study thus makes a contribution to the social and environmental accounting and accountability literature by taking prior research on sustainability reporting beyond the previously documented legitimacy and impression management strategy framework (see, e.g., Bansal and Kistruck, 2006; Beelitz and Merkl-Davies, 2012; Deegan, 2014; Du and Vieira, 2012; Merkl-Davies and Brennan, 2007; Neu et al., 1998; Patten, 1992; van Halderen et al., 2016). Using the frontstage and backstage Goffmanesque concepts, we uncover and document further the misleading nature of the discourse contained in stand-alone sustainability reports. Prior research has repetitively shown how sustainability reporting provided by corporations is inconsistent with their sustainability performance (Adams, 2004; Boiral, 2013; Patten, 2002), a finding which we further extend here by discussing the inconsistencies between publicly visible corporate reporting and their less visible political activities.

The remainder of the paper is organized as follows. The next section provides the theoretical development. Section 3 describes the empirical setting, including how corporate political strategies and sustainability reporting can be tied to backstage and frontstage, respectively. Sections 4 and 5 present the methods and findings for both the qualitative frontstage analysis and the quantitative backstage analysis. Conclusions, limitations, and future research opportunities are discussed in Section 6.

\section{Theoretical development}

Our theoretical framework is based on Erving Goffman's theory of selfpresentation (Goffman, 1959). Goffman uses a dramaturgical analysis, or theatrical metaphor, to explain how individuals attempt to manage the impressions others form 
about themselves. He maintains that individuals consciously assume roles to create impressions in the minds of others. Indeed, in the course of a social interaction, individuals accomplish performances like actors impersonate characters on stage. The purpose of the performance is to convey information to the others - termed the audience - in order to orient and control the impressions the audience will develop about the performer. As such, communication in all its forms is fundamental to Goffman's conception of impression management: "[Impression management] is achieved largely by influencing the definition of the situation which the others come to formulate and he [the individual] can influence this definition by expressing himself in such a way as to give them the kind of impression that will lead them to act voluntarily in accordance with his own plan" (Goffman, 1959, p. 3-4, emphasis added). Simply put, individuals accomplish this performance in order to lead the audience to perceive them as favorably as possible. To do so, performers pay significant attention to the information they communicate emphasizing some elements while underplaying others (Goffman, 1959).

According to Goffman, region occupies a central role in dramaturgical analysis and can be divided into frontstage ("on the scene") and backstage ("behind the scene"). Both regions are defined in relation to the position of the audience targeted by the performance. At the frontstage, individuals perform before the audience. The frontstage is where individuals present their official stance. They want the audience to perceive them a certain way and will develop and adjust their front performance in order to achieve this objective (see Jeacle, 2014). To this end, they will over-communicate some information and under-communicate other while seeking to demonstrate how their activities maintain 
certain standards and are aligned with social expectations (Goffman, 1959; Collinson, 1999).

Backstage, the performers are present but the audience is not allowed. This is where the performers prepare their frontstage performance and decide what information to put forward or leave behind during the actual show or play. Since the audience is not allowed backstage, this also is where the individuals can relax and "step out of character"; that is, stop playing their act, without the risk of destroying the impressions they managed to construct in the audience (see Jeacle, 2014). Elements of information suppressed or downplayed in the frontstage appear in the backstage context. In other words, the secrets of the show are kept backstage. Keeping secrets is essential to the protection of the impressions the performers want to generate in the audience. If they were to be known, secrets would discredit both the performance and the performers (Goffman, 1959).

Although Goffman's work moves primarily on the level of the individual (see Leary and Kowalski, 1990), we maintain here that like those of individuals, corporate attempts to manage public impressions about their activities through communication can be analyzed using the theatrical metaphor (Allen and Caillouet, 1994; McCormick 2007; Young and Massey, 1978). Allen and Caillouet (1994, p. 46), drawing on Goffman (1959), maintain that “organizations, like individuals, are 'actors`engaging in 'performances' in various 'settings` before 'audiences '”. This relates closely to the question of how we understand the organizational self and its identity, and whether we should treat corporate reports and communication as produced by some individuals within the organization or by the organization itself (see Cheney, 1992). As pointed out 
by Tregidga and colleagues (2014,p. 480), there is in the organizational communication literature a long tradition to consider organizational texts as "representations of organizations, and as a process of identification". In exploring how corporations come to represent themselves as sustainable organizations, Tregidga and colleagues (2014) argue that despite the fact that all corporate communication is produced by individuals or groups of individuals, such organizational texts "represent the organization and play a role in constructing organizational identity" (p. 480).

Along similar lines, White and Hanson (2002) analyze a long-standing debate regarding how ideas such as corporate identity and corporate image should be treated. In their analysis, White and Hanson (2002, p. 290) point out that in Goffman's work his discussion of the 'self is not restricted to the individual level and that he would perceive "the 'self as far more than an embodied individual". Thus, White and Hanson (2002) argue that a Goffmanesque analysis can be extended from the individual to a collective level, and thereby maintain that a corporation can be considered as a 'self in an analysis evoking Goffman's theatrical metaphors. Moreover, Tregidga and Milne (2006, p. 220) draw on Cheney (1992) and highlight how in the literature it is argued that organizations increasingly "are what they communicate".

Given the above and in line with Tregidga and colleagues (2014; see also Laine, 2010), we maintain here that how organizations represent themselves - and construct their discursive identities - in their communication has tangible implications on how their voice and actions are perceived in society. Not surprisingly, organizations have been noted to actively use communication in seeking to manage the impression their relevant audiences have of them (see Ashforth and Gibbs, 1990; Cheney, 1992). 
Accordingly, prior research has employed Goffman's dramaturgical metaphors to investigate corporate annual reports and other communication. White and Hanson (2002) show how a multinational corporation uses some of Goffman's impression management techniques in its annual report disclosure to build its corporate reputation. Previously, the work of Neu et al. (1998), illustrating how corporations use environmental disclosure in annual reports to manage public impression about their activities, is inspired by Goffman (1959). Jeacle (2008) studies the big four accounting firms' recruitment literature in light of Goffman's theory to illustrate how these firms manage impressions with the goal of counteracting the boring accountant stereotype and facilitate recruitment. In more direct connection to the study presented in this paper, Cho and Roberts (2010) situate Goffman's sociological theory of self-presentation within the organizational legitimacy framework and demonstrate how the content and presentational features of corporate websites are employed by corporations operating in environmentally sensitive industries to manage impressions about their environmental performance. Relatedly, Solomon and colleagues (2013) recently discuss how in corporate private environmental reporting "both investors and investees employ Goffmanesque, staged impression management as a means of creating and disseminating a dual myth of social and environmental accountability" (p. 195). They highlight that while "ritualistic impression management" in regard to sustainability information takes place in the frontstage, in the backstage financial reporting is prioritized in the financial investment institutions. Although Solomon and colleagues (2013) focus on private disclosures instead of publicly available corporate sustainability reports, their insights highlight the need for further explorations that contrast corporate frontstage disclosures with their more covert backstage activities. ${ }^{1}$

\footnotetext{
${ }^{1}$ Organizations have a range of stakeholders with different expectations and of varying power (e.g.
} 
Besides the work drawing on Goffman, there is a substantial body of research exploring corporate disclosures from various other impression management perspectives specifically in the oil and gas industry (e.g., Abdelrehim et al., 2015; Arena et al., 2015; Bell and Lundblad, 2011; Cho, 2009; Hooghiemstra, 2000; Du and Vieira, 2012; Matejek and Gössling, 2014; Michelon, 2012; Patten, 1992; van Halderen et al., 2016), in the water industry (e.g., Cooper and Slack, 2015; Ogden and Clarke, 2005) and in other settings (e.g., Bansal and Clelland, 2004; Boiral, 2016; Bozzolan et al., 2015; Brennan et al., 2013; Elsbach and Sutton, 1992; Higgins and Walker, 2012; Michelon et al., 2015; Neu et al., 1998; Sandberg and Holmlund, 2015; Talbot and Boiral, 2015; Talbot and Boiral, forthcoming; Tata and Prasad, 2015; Windsheid et al., 2016). In general, this prior research has shown how organizations use different impression management tactics to maintain or enhance their image (e.g. Ashforth and Gibbs, 1990; Beelitz and MerklDavies, 2012). Within the impression management literature, the key point is that with the various communication strategies organizations alter and fine-tune their disclosures in such a way that the relevant publics would form a positive (or at least neutral) view of the organization (see Bozzolan et al., 2015). It has also been argued that in some cases organizations engage in attempts to manipulate public perceptions in seeking to maintain their legitimacy in society (Cho, 2009; Ylönen \& Laine, 2015). Recently, Merkl-Davies, Brennan and colleagues have produced a series of papers (Merkl-Davies \& Brennan, 2007; 2011; Merkl-Davies et al., 2011; Brennan \& Merkl-Davies, 2013), in which they

Mitchell et al., 1997; Arenas et al., 2009). As pointed out by Goffman (1959), the context and setting will define what kind of an impression an actor seeks to convey, and to which audience. Therefore, we could expect to see attempts of creating and managing impressions differently in respect to each group of stakeholders (see also Bozzolan et al., 2015; Cho et al., 2015). As the purpose of this paper is to illustrate the usefulness of Goffman's frontstage/backstage analogy to corporate sustainability reporting research on a more general level, we maintain that an analysis of the interactions in regard to particular subsets of stakeholder audiences is beyond the scope of this paper. 
have - through an extensive review of prior literature -produced a detailed framework for distinguishing and analyzing the various impression management tactics that organizations engage in when interacting with their stakeholders. We acknowledge that this work has provided us substantial insights into how the organizations use their disclosures in attempts to convey favorable representations of them.

Simultaneously, however, we note that many contributions within this body of research focus merely on corporate communication (e.g. Merkl-Davies and Brennan, 2011), and do not necessary engage directly with the discrepancy between a corporation's disclosures and its actions. We posit that Goffman's dramaturgical metaphors provide illustrative vocabulary, which helps shed light on how corporations on the one hand make some aspects visible and prominent while on the other work to obfuscate or hide some other elements. Indeed, as noted by Milne and Patten (2002, p.375), organizations can seek "to conceal the 'back stage' activities from prying eyes". We maintain that Goffman's frontstage and backstage as well as his other conceptual tools within the dramaturgical framework are illuminating metaphors, and as such serve in further enhancing our understanding of the potential discrepancies between corporate talk and action, alongside other conceptualizations such as symbolic and substantive representation (Ashforth and Gibbs, 1990).

The use of Goffman's dramaturgical metaphors aids in broadening the theoretical and conceptual basis of corporate sustainability reporting research. A broad range of theories may be employed to study sustainability accounting issues (Gray et al. 2009). One of the most prevailing theories in sustainability accounting research is legitimacy theory (see e.g., Beelitz and Merkl-Davies, 2012; Deegan, 2014; Patten, 1992), which has 
however recently been under criticism for the lack of refinement of the approach and the simplistic assumptions it is based on (Deegan, 2014) as well as the limited scope of the theory (Spence et al., 2010).

Finally, it has also been pointed out (Unerman and Chapman, 2014) that the repeated use of a single theory may lead to the production of marginal contributions instead of creating compelling advances to knowledge. Accordingly, and despite acknowledging that our empirical setting could also be approached through concepts of organizational legitimacy, we opted for a less frequently used theoretical lens and thereby answer the repeated calls to employ original theoretical perspectives as an attempt to enrich the understanding of sustainability accounting and reporting (Bebbington and Thomson, 2013; Unerman and Chapman, 2014), as we maintain that Goffman's dramaturgical metaphor is employed only seldom in accounting research (aside from the articles we list above).

In summary, we will draw on Goffman's framework to analyze corporate activities and to further refine our understanding of corporate sustainability disclosures. More specifically, we argue that corporate activities can be divided into frontstage and backstage performance. Frontstage activities are externally oriented activities aiming to manage relationships with stakeholders in order to repair or maintain legitimacy, while backstage activities are internally oriented management activities aiming to foster corporate interests away from those same stakeholders' scrutiny. In the context of our study, we consider voluntary sustainability reporting in stand-alone reports as the frontstage corporate activities whereas corporate political strategies such as political 
campaign contributions are envisioned as backstage corporate activities, with the passage of the ANWR Bill constituting the empirical setting that generates potential conflict.

\section{Empirical setting}

\subsection{The Arctic National Wildlife Refuge and the American-Made Energy and Good Jobs Act}

The Arctic National Wildlife Refuge (ANWR) is located in Northern Alaska and covers about 19.8 million acres $\left(80,000 \mathrm{~km}^{2}\right)$ of the North Alaskan coast (Burger, 2001). It is managed by the U.S. Fish and Wildlife Service and constitutes the largest single protected wilderness area in the U.S. (League of Conservation Voters, 2005). The ANWR was first declared a federal protected area by Frederick Andrew Seaton under President Eisenhower's administration in 1960 before being further secured and backed by the Alaska National Interest Lands Conservation Act of 1980 (U.S. 96 ${ }^{\text {th }}$ Congress, 2009). One part of this legislation - section 1002 - postponed an important decision regarding future management of a designated 1.5 million acres $\left(6,100 \mathrm{~km}^{2}\right)$ coastal plain region referred as the "1002 area" because of its alleged large supply of crude oil and natural resources. Hence, because Congressional authorization was required before any activities could take place in the "1002 area", the question of whether to drill for oil in the ANWR has been used as a political device and subject to much debate and controversy in national media and U.S. politics since 1977 - even before the 1980 Act was passed (Waller, 2001; Shogren, 2005). ${ }^{2}$

\footnotetext{
${ }^{2}$ Such debate and controversy include the Canadian and US governments signing the "Agreement on the Conservation of the Porcupine Caribou Herd" (July 1987) aimed at protecting the species from damage to its habitat and migration routes; a bill allowing drilling that was stopped when the Exxon Valdez oil spill happened (March/April 1989); another legislation allowing drilling voted by the Republican-majority House and Senate but vetoed by President Clinton (1996); a controversy about reports issued by the U.S Geological Survey about the quantities and location of oil (1987 and 1998); and a series of votes about the
} 
Drilling opponents argue that oil exploration activities would significantly harm the natural wildlife. They also base their arguments on the U.S. Department of Energy reports on the uncertainty of the underlying resource base in the ANWR and its projected effects on oil price and supplies (U.S. Department of Energy, 2008). On the other hand, multinational oil companies, supported by most Alaskan officials, have been constantly lobbying federal legislators for Congressional authorization to drill in the refuge's sensitive coastal plain area, claiming that new domestic oil production would (1) help businesses expand by creating jobs, (2) contribute to economic growth, (3) make the U.S. less dependent on foreign energy sources and, (4) affect less than 1 percent of the coastal plain (Arctic Circle, 2009). Hence, the protection of Alaska's Arctic National Wildlife Refuge remains among the highest priorities for the U.S. environmental community. In March 2005, the ANWR was exposed to significant political debate. Drilling proponents in the U.S. Senate (hereafter, "Senate") managed to include Arctic Refuge drilling provisions in the federal budget process, hence avoiding a Democratic-led filibuster. While the Senate had narrowly passed its budget reconciliation bill calling for Arctic drilling language (Center for Responsive Politics, 2005), a bipartisan coalition in the $109^{\text {th }}$ U.S. Congress House of Representatives (hereafter, "House") with proconservation Republicans and Democrats was able to force the removal of the drilling language, along with offshore drilling provisions, in the final reconciliation bill. ${ }^{3}$ The

status of the ANWR in the House of Representative and the Senate ranging from pushing, approving and rejecting bills that allowed drilling.

${ }^{3}$ After failing to include Arctic Refuge drilling in the final budget reconciliation bill, Senator Stevens (RAK) made a last attempt to include language in the Defense Appropriations conference report. This attempt drew bipartisan opposition and the Arctic drilling language was ultimately abandoned (League of Conservation Voters, 2005). 
revised conference report was then approved by both chambers, keeping the ANWR safe from drilling (League of Conservation Voters, 2005).

ANWR was subject to another turbulent political year in 2006. House leaders again attempted to advance their ANWR drilling agenda—Richard Pombo (R-CA), Chair of the House Committee on Natural Resources (hereafter, "House Resources Committee") sponsored the American-Made Energy and Good Jobs Act, also known as stand-alone House Bill H.R. 5429 or under its popular name, the "Arctic National Wildlife Refuge Bill” (hereafter, "ANWR Bill”). While the ANWR Bill included some special provisions (in Section 3(e) and (f)) that would limit or exclude oil exploration in some special or closed areas, its overall primary purpose was to "direct the Secretary of the Interior to establish and implement a competitive oil and gas leasing program that will result in an environmentally sound program for the exploration, development, and production of the oil and gas resources of the Coastal Plain of Alaska, and for other purposes" (THOMAS, 2009). House Bill H.R. 5429 was introduced to the House on May 19, 2006 and passed on May 25 by a 225-201 vote ${ }^{4}$ (U.S. House of Representatives, 2009). However, pro-conservation House Republicans once again stood with Democrats to ensure that Arctic drilling was not included in the House budget resolution. As the two bills were never reconciled, the ANWR remains protected to date (League of Conservation Voters, 2006; Corn et al., 2015).

A timeline for both the key events related to the ANWR and the American-Made Energy and Good Jobs Act (H.R. 5429) is depicted in Appendix A. The top half of the appendix provides a timeline of the key events in the ANWR drilling debate. The bottom half of the appendix provides a timeline for H.R. 5429. The timeline for the ANWR

\footnotetext{
${ }^{4}$ This was done through House roll-call vote 209.
} 
drilling debate shows that ANWR has received political attention before and after the time period associated with H.R. 5429. However, the 2004-2006 timeframe represents the most critical time of debate and the most active period of concentrated corporate political activity that can be traced directly to ANWR.

Several facts related to the ANWR corporate political activities and related sustainability reporting support our focus on the 2004-2006 time period and on the debate over H.R. 5429. First, the 2004-2006 time period coincides with Congressional voting on a bill that would have allowed drilling and provides us an opportunity to empirically model the association between oil corporations' Congressional campaign support and legislator voting. Although legislative activities occurred after 2006 they never reached the same level of importance (Corn et al., 2015). Second, oil exploration activities are very expensive relative to other U.S domestic drilling efforts. Oil prices were at historic highs during this time period and provided more substantive economic arguments for allowing drilling in ANWR. Thus, the economic arguments for drilling in ANWR were strongest. Corn et al. (2015) report that the oil drilling costs per foot in Alaska as opposed to drilling in the lower 48 states, were 6.4 times higher in 2005, 18 times higher in 2009 , and 31 times higher in 2011.

Although the price of oil fluctuated significantly between 2005 and 2016, corporations' interests in drilling in ANWR seemed to drop significantly after 2006. Both Chevron and Marathon eventually withdrew operations from Alaska after 2006. ExxonMobil mentioned ANWR drilling only once after 2006, reporting in 2012 only that it had discussed ANWR with shareholders. Two of the corporations seemed to shift drilling interest to other parts of Alaska. ExxonMobil expanded exploration into Point 
Thompson and ConocoPhillips is interested in an area known as "The Greater Moose's Tooth Project." Our post-2006 analysis confirms that, while political debates continue regarding the potential environmental damage associated with oil exploration undertaken in environmentally sensitive areas, the level of debate over drilling in ANWR subsided significantly when the ANWR Bill failed to become law in 2006. Given its political and environmental ramifications, ANWR provides a relevant setting in which to apply Goffman's frontstage-backstage analogy to sustainability management and disclosure during the time period covering H.R. 5429 (Podesta and Boots 2015; Stolberg 2008; U.S. Department of Interior 2015).

\subsection{Political action committees}

Oil and gas corporations play an active role in the U.S. political scene. The industry has contributed over $\$ 251.6$ million since 1989 to federal candidates and political parties of which $77 \%$ were allocated to Republicans (Center for Responsive Politics, 2005, 2016). In particular, PACs ${ }^{5}$ from the Energy and Natural Resources sector had already outnumbered those from other industries throughout the mid-1980s and consistently ranked among the highest political campaign contributors (Center for Responsive Politics, 2010; Eismeier and Pollock, 1988). And, while corporate PACs contributed over $\$ 200$ million to congressional candidates during the 2006 election cycle,

\footnotetext{
${ }^{5}$ Corporate PACs are "political committees established and administered by corporations, labor unions, membership organizations or trade associations" and "can only solicit contributions from individuals associated with connected or sponsoring organization" (Federal Election Commission, 2010). They result from the Federal Election Campaign Act of 1971 (FECA) and its subsequent amendments in 1974, 1976 and 1979 (Cho, 2007). According to Smith (2000), the key commodity bestowed upon PACs is access; this means that "during deliberations leading to relevant legislative decisions, corporate political action committees (PACs) [...] get a respectful hearing from House and Senate members who have won election with the PAC's help" and that "corporations giving PAC contributions frequently receive 'face time' from members $[\ldots]$ and gain a valuable opportunity to present their perspectives" (p. 119). For more details on PACs, see Cho et al. (2006); Cho et al. (2008); Roberts et al. (2003); and Thornburg and Roberts (2008).
} 
the Energy and Natural Resources sector alone donated over \$22 million in PAC contributions during that same cycle (Center for Responsive Politics, 2010). More specifically, Cho et al. (2008) show how a sample of firms in the chemical and petroleum industries directed their PAC funds towards legislators deemed influential in a controversial piece of legislation that was passed in the U.S. immediately after the Bhopal disaster of 1984. The results of Cho et al. (2008) suggest that these industries sought to use their PACs in order to subvert legislation increasing corporate accountability on environmental pollution issues.

While PAC contributions are publicly available from the Centre for Responsive Politics' website (http://www.opensecrets.org) and other public sources, it is challenging to identify, compile, and analyze such information in a meaningful way. For example, the Center for Responsive Politics' website provides contribution amounts by each PAC given to federal candidates but not the total aggregate amount of PAC contributions received by a specific candidate (nor from which PAC those contributions come from). The challenges associated with extracting meaning from raw PAC information are likely to repel many stakeholders. The relatively contained dissemination of PAC information is also less likely to gain stakeholder attention in comparison to the easily accessible and neatly compiled sustainability reports. From an organizational perspective, the backstage region is conceived to be more intimate and only accessible to a closer group of actors in comparison to the frontstage (Cho and Roberts, 2010). This leads us to locate political strategies and contributions on the backstage. The backstage is where corporations can drop their environmental responsibility discourse, if desired, to foster their business interests without having to manage impressions (Goffman 1959). In the ANWR context, 
the primary interest of U.S. oil and gas firms is to be granted the rights to exploit the oil reserves of the wildlife refuge. It is therefore expected that they will design their political strategies in order to promote those interests. ${ }^{6}$ We will nonetheless also explore whether and how political contributions are present in the corporate sustainability disclosures to provide insights into our frontstage-backstage distinction.

\subsection{Sustainability reporting}

Because stakeholders are increasingly concerned with corporate environmental issues (e.g. Bansal and Hoffman, 2012; Cormier et al., 2004; Gray et al., 2014) and reporting (Rinaldi et al., 2014), sustainability reporting is considered to be on the frontstage since corporations publish these reports to manage their relationships with their stakeholders (Mallin et al., 2013; Rodrigue, 2014) as well as their reputation (Bebbington et al., 2008) and to demonstrate how their activities conform to social expectations (Bozzolan et al., 2015; Deegan 2014). Specifically, "narrative disclosures in [corporate] reports allow managers to stage and direct the play they wish the public to see, to pick the characters, to select the script and to decide which events will be highlighted and which will be omitted" (Neu et al., 1998, p. 269, paraphrasing Goffman, 1959). Stand-alone sustainability reports are designed to draw public attention to specific environmental issues selected by the publishing corporation (Gray et al., 2014), and to construct the image of environmental performance that corporations want the public to have about themselves (Apostol, 2015; Bansal and Kistruck, 2006; Boiral, 2016).

\footnotetext{
${ }^{6} \mathrm{We}$ acknowledge that corporations are not the only party seeking to promote their own interest, as in environmental issues there is also a range of NGOs and other social actors engaging in political lobbying (see Doh and Guay, 2006). Some NGOs lobbied for the protection of ANWR. We do not discuss such proenvironment lobbying here, as our paper focuses on discussing the differences within corporations' activities in light of Goffman's theatrical metaphor.
} 
Corporations have the opportunity to employ these reports to get stakeholder attention and reap the associated benefits of their described sustainability behavior (Madsen and Rodgers, 2015). In the ANWR environmental context, frontstage behavior on the part of oil and gas companies would translate into the use of narratives in their sustainability reports to emphasize their concerns about environmental protection and performance, in Alaska or elsewhere. Aware of stakeholders' environmental concerns and expectations, companies would report such information to manage stakeholder impressions about their environmental performance; that is, they would want to appear environmentally responsible in the eyes of their audience (White and Hanson, 2002).

\section{Research method}

The controversy surrounding the passage of the ANWR Bill provides the empirical setting for our study of how frontstage and backstage concepts can be utilized to better understand sustainability management and disclosure. We first turn to the qualitative study of the corporate frontstage performance of oil and gas firms in their sustainability reports, and then quantitatively analyze their backstage performance through their political strategies, using a political action committee empirical model. The ultimate purpose of our approach is to compare the frontstage environmental performance portrayed in corporate reports with the backstage usage of PACs to influence votes for the passage of the ANWR Bill. We contend that our multi-method approach to this issue enriches our analysis (Grafton, Lillis and Mahama, 2011) by recognizing that both discourse and numerical evidence are conveyors of meaning necessary to better understand a complex phenomenon (Malina, Nørreklit and Selto, 2011). Our qualitative 
findings allow us to draw additional inferences about the broader corporate context of our PAC analysis (Malina, Nørreklit and Selto, 2011).

\section{Qualitative approach}

To be considered in our study, U.S. oil and gas companies needed to have, during the ANWR Bill debate period, 1) published sustainability reports and 2) made political contributions. These criteria resulted in focusing our attention on seven large and highly visible U.S. multinational oil and gas corporations representing approximately $75 \%$ of the market share in the oil and gas industry during that period (see Table 1 for a list of the seven companies). ${ }^{7}$ As larger companies both tend to have broader political influence (see e.g., Scherer and Palazzo, 2011) and are known to publish more sustainability disclosures (Buhr et al., 2014), we maintain that such a sample provides us with a sound opportunity to contrast corporate sustainability reporting practices with their political lobbying activities. We examined the stand-alone sustainability reports ${ }^{8}$ of the selected companies to assess how their perspectives on the environment were presented in their sustainability report narrative disclosures. We were particularly interested in their position and discourse on biodiversity protection since it constitutes a major issue in the ANWR context. We collected and examined the available 2003-2005 sustainability reports because those were published from 2004 to 2006, which corresponds to the period

\footnotetext{
${ }^{7}$ While three other U.S. oil and gas companies made PAC contributions during the study period (Devon, El Paso and Valero), they did not issue sustainability reports in parallel, which lead to their exclusion of our analysis. As an indication of the market share, we computed the 3-year average proportion of our sample firms' revenues over the overall total revenues of all firms with the same Standard Industrial Classification (SIC) codes. Those codes were 1311 (Crude Petroleum and Natural Gas), 1389 (Oil and Gas Field Services) and 2911 (Petroleum Refining).

${ }^{8}$ For the sake of simplicity, we consider under "sustainability reports" any corporate stand-alone report labelled "Environmental, health and safety report", "Sustainable development report", "Social responsibility report", "Corporate citizenship report", "Corporate responsibility report" or any other similar title.
} 
during which the Arctic National Wildlife Refuge started to be targeted by the ANWR Bill. Examining the reports published during this period allows us to draw analyses between the policies and activities highlighted in the reports on the frontstage and the corporate political activities and strategies undertaken by the oil and gas industry leaders on the backstage (Goffman, 1959). In total, 21 reports were collected for seven corporations. ${ }^{9}$ Despite being relatively small in absolute numbers, our sample includes all the sustainability reports published in our study period by the seven U.S. oil companies, hence allowing us a sufficient basis on which to build our discussion of corporate activities. GRI G2 (2002) was in effect at the time these reports were published. Four out of seven companies do not refer to the GRI in their reports; one company mentions starting the alignment of its reporting with GRI in its 2004-2005 report; and the two remaining companies mention that their 2004 and/or 2005 reports are informed by or mostly consistent with GRI G2.

We use a qualitative content analysis to examine the reports (Bryman and Bell, 2015). We first imported the reports into the Atlas.ti software (Atlas.ti, 2004), which we mainly used to organize the data and provide a structure to data analysis. Drawing on the analysis of the ANWR case and the review of corporate documents, the authors generated the codes to be used in the analysis. After the initial coding of all relevant information, all codes were reviewed to verify the reliability of the coding. Any inconsistency was investigated and adjusted if necessary and a final review of all codes was performed to further ensure coding reliability. Following Langley (1999), a narrative strategy for data

\footnotetext{
${ }^{9}$ Four companies had three sustainability reports available for years ended 2003 to 2005 , respectively. In addition to its sustainability reports, one of these companies had also their Environmental, Health and Safety (EHS) reports for those three years. One company had sustainability reports only for years ended 2003 and 2004, another had them only for years ended 2004 and 2005 and a third had a 2003 report and one combined report for years ended 2004-2005.
} 
analysis was used to analyze the information content of each code. This first step resulted in a representation of the type of disclosure included in each coding category. The analysis then moved onto what Langley (1999) calls a visual mapping strategy, in which data is organized in a systematic visual format (Miles and Huberman 1994). In this step, matrices were used to group codes and their associated quotations into main categories according to common themes (O'Dwyer, 2004). The two major code categories that emerged from the grouping were corporate environmental commitment and biodiversity protection. Matrices were then employed to analyze the information from each category through a within-category analysis method to identify trends and to summarize each main theme. Categories were then compared using a cross-category approach in order to identify relations between corporations' views on the protection of the natural environment. Moreover, in seeking to provide further insights in regard to the positioning of corporate political activities on the frontstage-backstage continuum, we also explored whether corporations provide in the disclosures information about their political position, contributions and other activities.

\section{Quantitative approach}

We examined quantitative evidence related to the lobbying activities of the same oil and gas companies in order to assess their political strategies. Our examination consists of two separate empirical analyses. First, we constructed an empirical model that includes PAC contribution amounts from oil and gas firms received by members of the $109^{\text {th }}$ U.S. Congress House of Representatives (hereafter, "House members"). To explain political factors associated with their contribution decisions, we focus on House 
Resources Committee members of the $109^{\text {th }}$ Congress because of their close involvement with natural resources management. We argue that when legislation such as the ANWR Bill is pending, oil and gas firms will become more active on the political stage by making significantly higher PAC contributions to a select group of pertinent and influential legislators (Cho et al., 2008; Roberts et al., 2003; Thornburg and Roberts, 2008) such as House Resources Committee members.

Second, we constructed a voting model that tests whether legislators receiving significant campaign contributions from the PACs of the seven oil and gas companies were likely to vote in favor of opening ANWR to allow drilling to take place. A significant, positive relation between the legislator's support for the ANWR Bill and the amount of campaign support received from these oil companies would suggest that the companies' political strategies show much more concern for core drilling activities and much less concern for protecting the environment.

Sample

The unit of analysis for the empirical model is each member of the $109^{\text {th }}$ Congress U.S. House of Representatives. To be included in the sample, members had to have cast a vote on the ANWR Bill, and have a 2006 League of Conservation Voters (LCV) ${ }^{10}$ Congress member voting record score as well as their party affiliation available. Of the 435 members, 9 did not vote on the Bill due to excused or unexcused absences, vacant seat and ineligibility to vote. As a result, the final sample includes 426 House members.

\section{Measurement of variables}

\footnotetext{
10 The League of Conservation Voters (LCV) publishes annually a report called "How the $\mathrm{xx}^{\text {th }}$ Congress voted on Energy and the Environment". It provides ratings on how each Congressman performed in voting for legislations related to the environment. In addition, it provides an objective roll-call vote record of key environmental legislations. The $109^{\text {th }}$ Congress voted on numerous issues, which included the ANRW Bill.
} 
PAC contributions from the U.S. oil and gas industry

Our research interest is in (1) large U.S. oil and gas firms and how much their political action committees contributed to political campaigns; and (2) whether those contributions appear to significantly affect the voting behavior of House members. PAC expenditures made for campaign contributions must be disclosed to the FEC and information on corporate political spending is available from the Center for Responsive Politics. This variable is measured by the total hard dollar amount of campaign contributions made by the seven U.S. oil and gas industry firms to members of the $109^{\text {th }}$ U.S. House of Representatives during the 2004 and 2006 election cycles.

\section{Membership in the House Resources Committee}

As discussed earlier, the House Resources Committee under the $109^{\text {th }}$ U.S. Congress had jurisdiction over House Bill H.R. 5429. Consequently, we predict that members of this particular Committee received higher amounts of PAC contributions than their non-member counterparts. The test variable is a binary variable coded as "yes" (or "1") if the Representative is a member of the Resources Committee and "no" (or "0") otherwise. We use the Committee rosters in the $109^{\text {th }}$ Congressional Directory to determine their membership.

Vote on the Arctic National Wildlife Refuge Bill (House Bill H.R. 5429)

This binary variable is coded as " 1 " if the Representative voted for the passage of ANWR Bill and "0" otherwise. The voting record (House roll-call vote 209) was obtained from the U.S. House of Representatives - Office of the Clerk. Control variables 
We control for other factors that may affect firms' allocations of PAC contributions and/or a House member's voting behavior. Two control variables are frequently used in PAC contribution models and roll-call voting models - legislator ideology and political party affiliation (see, e.g., Roberts et al., 2003; Cho et al., 2008). A legislator's ultimate goal is to be re-elected; the two most fundamental resources needed for re-election are votes, which can only be given by constituents living in the legislator's home district, and money, which can be provided by a number of sources. In general, votes and money flow to legislators who supply the legislation that is desired by their voting constituents and their moneyed interests. Thus, both the legislator's ideology and party affiliation are a predictable signal to the political market about the types of legislation that a legislator will supply in the future (Roberts et al., 2003; Cho et al., 2008). In this study, legislator ideology is represented by the legislator's voting record score computed by the LCV. This score is obtained by dividing the number of proenvironmental votes by the total number of votes actually cast, ignoring absences. Higher ratings will thus be pro-environment. The party affiliation control variable is a binary variable, which is coded as " 1 " if the House member is affiliated with the Republican Party and "0" otherwise. These records are available from the $109^{\text {th }}$ Congressional Directory.

\section{Regression models}

We tested whether Resources Committee members of the $109^{\text {th }}$ Congress received significantly higher amounts of PAC contributions from firms operating in the U.S. oil and gas industry than their non-member counterparts. We conducted a cross-sectional regression analysis, controlling for legislator ideology and party affiliation. We included such control variables because we seek to isolate these effects on campaign contributions 
from our membership test variable. Because PAC contributions, our dependent variable, cannot be negative, we used Tobit analysis to estimate our regression model (see, e.g., Cho et al., 2008; McDonald and Moffitt, 1980; Roberts et al., 2003). The Tobit model is stated as follows:

$$
\text { OIL_GAS_PAC }=a_{1}+b_{1} C O M \_R E S O U R C E S+b_{2} \text { PARTY }+b_{3} L C V
$$

where:

OIL_GAS_PAC = PAC dollar contributions made by firms in the U.S. oil and gas industry to members of the $109^{\text {th }}$ U.S. House of Representatives during the 2004 and 2006 election cycles;

COM_RESOURCES = Dummy variable, 1 if the Representative is a member of the House Resources Committee under the U.S. $109^{\text {th }}$ Congress, 0 otherwise;

PARTY = Dummy variable, 1 if the Representative is affiliated with the Republican party, 0 otherwise;

$\mathrm{LCV} \quad=$ Representative's environmental voting record score assessed by the League of Conservation Voters.

One of the key goals of a PAC is to influence the voting behavior of legislators on the issue(s) of interest (Roberts et al., 2003). We determine the effectiveness the campaign contributions made by PACs from firms in the U.S. oil and gas industry by examining the relation between those PAC dollar amounts and roll-call votes on House Bill H.R. 5429. Because of the binary nature of the roll-call vote variable, we used logistic regression to test the effectiveness of such political strategies. The logistic model is stated as:

$$
\mathrm{VOTE}=\mathrm{a}_{1}+\mathrm{b}_{1} \text { OIL_GAS_PAC }+\mathrm{b}_{2} \text { PARTY }+\mathrm{b}_{3} \mathrm{LCV}^{11}
$$

where:

\footnotetext{
${ }^{11}$ A preliminary multiple regression was conducted to calculate Mahalanobis distance (to identify outliers) and examine multicollinearity among the three predictors. Tolerance for all variables was greater than 0.1 , indicating that multicollinearity is not a problem in this model. There were two cases with a Mahalanobis distance greater than $\chi^{2}(3)=16.266$ (critical value at $p=0.001$ ). We ran the model both with and without these outliers and the results were qualitatively the same.
} 

VOTE
$=$ Dummy variable, 1 if the Representative voted for House
Bill H.R. 5429, 0 otherwise;
OIL_GAS_PAC = Natural log of PAC dollar contributions made by firms in the
U.S. oil and gas industry to members of the $109^{\text {th }}$ U.S. House of
Representatives during the 2004 and 2006 election cycles;
PARTY
$=$ Dummy variable, 1 if the Representative is affiliated with the
Republican party, 0 otherwise;
LCV
$=$ Representative's environmental voting record score assessed by the League of Conservation Voters.

\section{Findings}

\subsection{Qualitative findings}

Our analysis indicates that all corporations used their sustainability reports to

emphasize their concerns for environmental issues and to express their commitment

towards environmental protection. The excerpts from sustainability reports presented

below are examples of typical disclosures made in this respect.

ExxonMobil is committed to operating responsibly everywhere we do business by implementing scientifically sound, practical solutions to meet energy needs in an environmentally responsible manner (ExxonMobil 2005, p. 20, emphases added).

To achieve our goal of HSE [Health, Safety and Environmental] excellence, we are committed to integrating HSE practices into all of our business activities by adhering to the following goals: · Creating incident-free work environments; Conducting business with no adverse environmental impacts; Demonstrating industry leadership in HSE performance. (Halliburton, 2003, p.8, emphases added)

Environmental stewardship means more than keeping track of emissions and waste statistics. It is a genuine commitment to minimize the impact our operations have in the communities where we live and work (Marathon 2004, p. 9, emphases added).

Although different in formulation, all excerpts carry the same message - environmental protection occupies a significant stance in corporate operations and it drives the manner in which corporations perform their activities. While the above quotes refer to past or 
present years, corporations also use sustainability reports to emphasize their

environmental commitment for the years to come:

Koch companies worldwide will manage operations in a manner that protects the environment and the health and safety of employees, customers, contractors and the public while fully complying with applicable laws and regulations (Koch 2003, p. 2, emphasis added).

As we move forward, we will continue to seek the most effective solutions to promote sustainable and environmentally sensitive development and to enhance our programs in order to help meet local needs. We are proud of our accomplishments to date, and we will continue to operate in a manner that respects human rights, protects the environment, and generally improves the quality of life for our employees and our communities around the world (Occidental 2003b, p. 1, emphases added).

In parallel to these overarching commitments to protect the environment, some corporations also state their dedication to preserve biodiversity-a central issue in the

ANWR debate. Again, these concerns cover current and future corporate operations:

Chevron works to protect sensitive ecological habitats and species around our operations by focusing on biodiversity conservation. (...) Oil and gas operations may affect biodiversity through both direct impacts (such as physical footprints) and secondary impacts (such as enabling access to previously inaccessible areas) (Chevron 2004, p. 58, emphases added).

ExxonMobil recognizes the protection of biodiversity - the variety and complexity of life - as an important conservation issue that presents broad challenges to society. We believe we can operate responsibly in sensitive areas by implementing scientific, practical and sustainable solutions. Protecting biodiversity is a fundamental part of our environmental management system and is considered during our business planning and across all aspects of our operations. (Exxon, 2003, p.10, emphases added)

The above quotes illustrate how corporations recognize the environmental issue of biodiversity protection as an environmental concern in itself and how they claim to integrate this issue in their overall environmental approach. Examples 
of initiatives implemented for biodiversity protection are sometimes offered in complement to specific environmental concerns. These initiatives took place in different regions of the world, from coastal lines to tropical forests. Exxon, for instance, details various biodiversity initiatives it implemented or worked on in partnership with governments and/or other stakeholders. Other initiatives are as follows:

We are an active participant in energy industry efforts on biodiversity (...). Key efforts in this regard are encouraging broader industry testing and use of EBI [Energy and Biodiversity Initiative] tools and guidelines, and holding workshops in a number of regions to build relationships with key stakeholders and share best practices on biodiversity conservation. (Chevron, 2004, p.58, emphasis added)

Biodiversity monitoring does not indicate significant impacts to mammals, birds, amphibians/reptiles, fish or macro-invertebrates. All canopy bridges were successfully installed and movement of arboreal mammals, primarily monkeys, has been observed. This innovative project received two awards for showing how sustainable development concepts can be integrated into oil development. (Occidental, 2003a, p.7, emphases added).

In the context of ANWR, two initiatives are worth mentioning as they took place in Alaska. First, Marathon (2004) presents its Kenai Gas Field operations in the Cook Inlet Region of Alaska as a testimony of the firm's commitment to minimize its environmental impacts, including biodiversity protection. The firm explains its commitment by highlighting it "has worked to reduce emissions and protect wildlife habitats as part of its natural gas operations" (2004, inside cover page, emphasis added) in the area. Second, ConocoPhillips (2004) recognizes the sensitive ecosystems present in the Alaska North Slope and states how oil exploration and development activities need to be pursued while protecting the environment. 
Altogether, with these disclosures, our case firms portray themselves as aware and sensitive to the delicate biodiversity issues associated with their worldwide (and Alaskan) operations. Strictly based on this voluntarily disclosed information, it can be inferred that these companies are sufficiently sensitive to environmental issues related to the ANWR context.

Overall, the information on environmental performance provided in stand-alone sustainability reports emphasizes the care given to environmental protection in corporate operations. At the frontstage of their environmental management, corporations picture themselves as responsible companies that not only acknowledge but also deal with their environmental issues to improve their environmental performance. A tight match between the corporations' portrayal and their actions would suggest that their political strategy would be aligned with their expressed environmental commitment.

\section{Disclosures on political contributions}

Before moving on to analyze corporate political activities through their PAC contributions, we will explore first whether and how political contributions appear on the frontstage in our setting by examining the information on lobbying activities provided by the corporations in their own sustainability reports.

Goffman (1959) recognizes that clear-cut frontstage and backstage situations are not to be expected due to the multiple performances played simultaneously to different audiences (see also Ross, 2007). He instead suggests that "in a concrete situation, we may expect a predominance of one style or the other" (p. 129). In the context of our study, such clear-cut frontstage/backstage performance would be found, for example, if 
backstage political strategies ${ }^{12}$ related to environmental legislation were not mentioned in the frontstage sustainability report discourse. Although very limited in number, we find, however, that three of the seven firms analyzed mention some of their political activities in their sustainability reports. One firm expresses its consistency between its environmental commitment and its participation in public policy:

ConocoPhillips engages in public policy discussions through different means, including membership in trade associations involved in public policy issues, research, and direct lobbying campaigns on specific issues. The company's current public policy areas of emphasis are energy policy, fuel standards, climate change and clean air issues, and industry health, environment, safety and social issues (ConocoPhillips 2004, p. 15, emphases added).

In line with the corporation's publicly reported environmental commitment (see the previous section), environmental issues appear to be part ConocoPhillips' public policy engagement. However, this consistency still raises questions; both the nature of the environmental issues and the purpose of the corporation's political campaign are vaguely described at best, leaving users wonder what issues the corporation advocates for and what environmental position it adopts as part of its political strategy.

Similarly, the disclosures of other sampled corporations regarding political contributions and activities published remain - when present - equally vague. Chevron, for instance, emphasizes how in making political contributions it both supports candidates who have a pro-business mindset but also considers their approach on issues that Chevron perceives to be important. Given that in its sustainability reports the company emphasizes the importance of environmental issues to the company and the need to demonstrate "exemplary" environmental performance (Chevron, 2004, p. 6), on

\footnotetext{
${ }^{12}$ We define political strategies as the means used by corporations to influence public policy—these include but are not limited to including political contributions, PACs and lobbying (see Hillman and Hitt, 1999; Mack, 1997).
} 
the frontstage it remains unclear how Chevron directs its political contributions.

Similarly, the only thing Exxon mentions about the recipients of its contribution is as follows:

Designations of PAC funds are made to candidates who favor the strengthening of the free enterprise system and hold views consistent with the best interests of ExxonMobil Corporation. (ExxonMobil, 2005, p. 63).

Akin to Chevron's, the way ExxonMobil directs its contribution is vague and ambiguous.

According to the GRI G2, companies are expected to disclose a description of their policies, procedures and compliance mechanisms for managing political lobbying and contributions (core indicator SO3) and may provide the related amount of money paid (additional indicator SO5) (GRI, 2002). Two of the three companies reporting information on their political contributions affirm their reporting is informed by the GRI (G2). Chevron claims full coverage of both indicators in 2004 and 2005, while Exxon (in 2005) only mentions reporting the indicators, without further reference to coverage level. Our analysis suggests that both companies are generally compliant with the guidelines for SO3 and SO5. Undoubtedly, more information could have been provided to further detail policies, procedures and mechanisms. However, we contend that the most problematic issue does not lie within the level of compliance with current GRI indicators, but rather lies within the limitations of the GRI itself. Our analysis of political contributions disclosure in light of environmental protection issues exposes the almost complete absence of links drawn between the two issues - while being generally compliant with the GRI guidelines of the time. We learn very little about the environmental inclinations of the political activities and/or about the recipients of the contributions. Thus, our analysis is yet another example of what the GRI does not show (Moneva et al. 2006; 
Boiral, 2013) and of the absence of integration among social, environmental and economic issues it produces (Milne and Gray, 2013).

Therefore, we argue that even if some disclosures about political contributions and activities were made, little information is released about how the contributions relate to political decision-making on environmental matters. We hence maintain that any specific information of corporate political activities and contributions remains hidden from the public eye, and therefore position these in the backstage. We will next seek to discuss such backstage activities by providing an analysis of the PAC contributions of the sampled companies.

\subsection{Quantitative findings}

We first note that out of the total amount of PAC contributions of $\$ 3,776,400$ made by our seven sample firms, $\$ 3,229,350$ (85.5\%) were given to Republicans and $\$ 547,050(14.5 \%)$ to Democrats. Summary data on PAC contribution amounts given by each firm is provided in Table 1 Panel A.

During the 2004 and 2006 election cycles, ${ }^{13}$ there were 228 members affiliated with the Republican Party, 197 Democrats and one independent. Out of these 426 voting Representatives, 59 were members of the House Resources Committee, including leadership Chair and Vice-Chair positions. As discussed above, the ANWR Bill was passed with 225 (52\%) favorable votes versus 201 (48\%) against, as a simple majority of 214 votes was required. In terms of PAC dollar contributions received, the mean PAC dollar contribution amount received by committee members $(\$ 13,408)$ is significantly

\footnotetext{
${ }^{13}$ Members of the U.S. House of Representatives serve two-year terms. Hence, as we focus our analysis on vote for/against the ANRW Bill in March 2006, we examined membership and PAC contributions data from 2004 to 2006 within their respective election cycles.
} 
higher than their non-member counterparts $(\$ 8,134)$ (at the $p<.05$ level, two-tailed). Summary data on the members of the $109^{\text {th }}$ Congress House of Representatives is provided in Table 1 Panel B.

[Insert Table 1 about here]

Because House Bill H.R. 5429 was referred and assigned to the House Committee on Natural Resources, we investigated the composition of this particular committee during the 2004 and 2006 election cycles. Among the 59 House Representatives who were members of this committee during these periods, 27 committee members were affiliated with the Democratic Party versus 32 Republicans. Twenty-three committee members voted against the ANWR Bill but 21 of those opponents were Democrats. PAC dollar contributions received by committee members who voted against the Bill totaled $\$ 28,100$ while contributions received by committee members in favor of the ANWR Bill totaled $\$ 763,000$. Further, the mean PAC dollar contribution amount received by committee members in favor of the ANWR Bill $(\$ 21,194)$ is significantly higher than that of members who voted against it $(\$ 1,222)$ (at the $p<.001$ level, two-tailed). We present detailed information and statistics related to the House Resources Committee in Table 2.

[Insert Table 2 about here]

Results of the Tobit regression model testing the relation between PAC contributions made by firms in the U.S. oil and gas industry and Resources committee membership during the 2004 and 2006 election cycles are provided in Table 3.

[Insert Table 3 about here]

Resources Committee membership is positively associated to the 2004 and 2006 election cycle PAC contributions made by U.S. oil and gas firms $(p<.05$, one-tailed). 
That is, those firms contributed significantly more to Representatives who are members of the Resources Committee than to their non-members counterparts. The LCV control variable is also significant with respect to its expected signs (at the $p<.01$ level, twotailed) but the political party control variable is not significant. The overall model is significant and the explanatory power is relatively high as illustrated by an adjusted pseudo R-squared of $0.228 .{ }^{14}$ Similar to Roberts et al. (2003) and Cho et al. (2008), these results confirm previous findings that firms strategically allocate PAC contributions to support political campaigns of federal candidates who hold membership in the congressional committee(s) of interest.

Logistic regression was also conducted to determine which independent variables were predictors of the vote favoring the passage of the ANWR Bill. Regression results show that the overall model indicates a good fit and is statistically reliable and significant in distinguishing between a favorable and a non-favorable vote $(-2 \log$ Likelihood $=$ 88.825; Hosmer-Lemeshow Test for Goodness-of-Fit $\left.\chi^{2}=4.982, p=0.760\right)$. In addition, the explanatory power of the model is high with a Nagelkerke R-squared of $0.922 .{ }^{15}$ Regression coefficients are presented in Table 4. Wald statistics indicate that the PAC contributions made by firms in the U.S. oil and gas industry were positively associated to the vote favoring the passage of the ANWR Bill $(p<.1$, one-tailed). As to the control variables, both coefficients are significant ( $p<.01$ level, one-tailed).

[Insert Table 4 about here]

\footnotetext{
${ }^{14}$ Similar to Cho et al. (2008), the DECOMP based fit measure generated by the Tobit regression model is taken and labeled as the adjusted pseudo R-squared.

15 This model is a binary logistic regression, thus the Nagelkerke R-squared provides a logistic analogy to the adjusted R-squared in OLS regression.
} 
Overall, our results indicate that large U.S. oil and gas firms appear to have sought to exercise considerable influence on the passage of the ANWR Bill. More specifically, our findings indicate that these firms made significantly higher PAC contributions to members of Congress who hold influential positions (i.e., members of the House Resources Committee) in the passage of environment-related legislation and allocated significantly higher contribution amounts towards members in favor of the ANWR Bill. Second, our analysis provides some evidence aligned with the assumption that PAC contributions from the oil and gas industry had an impact on the roll-call vote cast by House Representatives in their favor. Hence, their political strategies appear to have been effective in influencing voting behavior.

\section{Discussion and conclusions}

Using ANWR to define regions in sustainability management, the purpose of this paper was to illustrate how Goffman's frontstage and backstage analogy can be useful to provide insights into sustainability disclosure. To this end, we contrast the frontstage sustainability discourse of a sample of large U.S. oil and gas firms to their backstage corporate political activities in the context of the passage of the Arctic National Wildlife Refuge Bill (H.R. 5429). Using a qualitative approach, we analyzed the available standalone sustainability report disclosures provided by seven corporations during the 20042006 deliberation period of the ANWR Bill. We also investigated these firms' corporate political strategies, notably their activities associated with political action committees, through quantitative empirical political strategy and effectiveness models.

The frontstage discourse on performance (sustainability reports) and the backstage actions (political strategies) of oil and gas companies reflect two conflicting 
approaches in regards to ANWR. In front of the audience, corporations enact a performance of environmental responsibility aimed at managing the impressions of their stakeholders by forging a specific image of them. Our analysis of sustainability reports highlights how oil and gas companies put forward their concern for present and future environmental protection. Commitment to biodiversity protection - including in the Alaskan region - also is underlined in the reports. The emphasis put on these elements exemplifies a form of "dramatic realization" in the companies' on-the-scene performance. This element of performance is employed by the performers to stress significant behavioral characteristics they want the audience to notice (Goffman, 1959). A notable example of dramatic realization is found in the detailed biodiversity initiatives sometimes included in the reports. The level of details provided by some firms to explain specific, often small-scaled, initiatives appear to be used to overemphasize and accentuate the commitment to biodiversity protection.

Aside from these detailed initiatives, we notice that most of the information conveyed in the sustainability reports is generic, composed of rather uninformative or even meaningless sentences expressing broad unsubstantiated commitments to environmental or biodiversity protection, with very few allusions to Alaska and no direct allusions to ANWR. This is consistent with frontstage behavior. Indeed, Goffman (1959) highlights that frontstage information is characterized by abstractness and generality. Such abstractness and generality is meant to allow the audience to more easily associate the performance with prevailing social standards, norms or expectations, in our case the protection of a wildlife refuge. Similar findings were observed by Holder-Webb and Cohen (2012), who expose generic boilerplate corporate codes of ethics issued in 
response to Section 406 of the Sarbanes-Oxley Act. A polished and controlled

performance is also characteristic of the frontstage, which could help explain the generic nature of the information found in the reports and the absence of concrete disclosure about ANWR. Avoiding ANWR within the sustainability reports is a way to control the message sent to the audience through front stage performances.

Behind the scene, oil and gas companies step out of their environmentally responsible character and can safely cease the management of impressions. Specifically, their alleged concerns for environmental stewardship, and particularly biodiversity protection, appear to be set aside. Corporations instead concentrate their efforts on lobbying for drilling for oil and gas within the geographic area declared by government as a wildlife refuge. This approach represents a typical backstage behavior, where backstage is "a place, relative to a given performance, where the impression fostered by the performance is knowingly contradicted as a matter of course" (Goffman, 1959, p. 112).

These findings highlight the necessity for oil and gas firms to conceal some information (their political activities) to sustain their impression of environmentally responsible corporations required by social norms (Goffman, 1959). Such concealment takes the form of secrets. In the present situation, a secret about specific pro-business and anti-environment lobbying activities would be qualified as "strategic" by Goffman; that is, a secret "pertain[ing] to intentions and capacities of a team which it conceals from its audience in order to prevent them from adapting effectively to the state of affairs the team is planning to bring about" (1959, p. 142). These specific types of lobbying activities can be envisioned as a strategic secret in that corporations want to hide their 
intention to drill the coastal plain of the refuge to prevent stakeholders from taking harmful actions such as activism (see Doh and Guay, 2006; Reid and Toffel, 2009) or challenging their organizational legitimacy (see Dowling and Pfeffer, 1975). One might even argue that lobbying activities constitute in fact a dark secret, defined as "facts about a team which it knows and conceals and which are incompatible with the image of self that the team attempts to maintain before its audience" (Goffman, 1959, p. 141). Indeed, the self-presentation of environmental stewardship found in the corporate sustainability reports clearly clashes with the lobbying activities of the oil and gas corporations targeting a wildlife refuge for drilling.

These findings are of high societal and ethical concern as the current voluntary and unregulated sustainability reporting scheme allows organizations to project an image and discourse characterized by significant bias, impression management and deception. While prior research (e.g., Clarkson et al., 2008; Mallin et al., 2013; Neu et al., 1998; Patten, 1992) examined the relation between sustainability disclosure and firm social and environmental performance, our study adds to this body of literature by looking at proactive lobbying efforts. More specifically, those very efforts and attempts constitute a carefully designed and proactive strategy, which sharply contrasts with the discourse contained in corporate sustainability reports. Hence, our usage of Goffman's frontstage and backstage regions contributes to the advancement of sustainability accounting research by identifying and connecting in more depth the complex mechanisms and multifaceted motivations behind sustainability reporting. Combining our findings with prior impression management work suggest that sustainability disclosures are not only 
used to conceal poor environmental performance, but also to divert attention away from economically driven political contributions.

Several implications can be drawn from our study. Our findings underscore the importance of accessible public records. The availability of PAC records was instrumental to exposing backstage activities in our empirical setting. Corporate voluntary reporting appears bound to being self-serving and biased (Boiral, 2016; Cho et al., 2015; Milne and Gray, 2013), which makes it challenging for any external parties to evaluate corporate performance and the subsequent impact of these activities on the basis of corporate disclosures only. In this respect, our study highlights the importance of maintaining accessible and comprehensible public records, from which stakeholders could gather further information about corporate activities, thus narrowing the backstage. Similarly, our findings support prior work highlighting the importance of multiple voices in sustainability reporting to foster a broader (and hopefully more complete?) portrayal of corporate activities (Apostol, 2015; Rodrigue 2014; Thomson et al., 2015). This stream of research underscores the importance of alternative accounts of corporate activities, published by non-corporate sources, to provide additional views on firms' social and environmental performance.

Furthermore, our study also joins previous work in raising concerns regarding impression management noticed in other mechanisms purportedly designed for sustainability management, such as mandatory reporting (Chen et al., 2014; CriadoJiménez et al., 2008; Luque-Vilchez and Larrinaga, 2016) and governance (Rodrigue et al., 2013). Accordingly, serious concerns continue about whether leaving sustainability management practices mostly in the hands of private corporations is in fact a sustainable 
idea from the broader social and ecological perspectives (Milne and Gray, 2013).

Moreover, and given in particular the significance excessive use of fossil fuels has on the acceleration of climate change and disappearance of biodiversity, we argue that it is pertinent that scholarly work explores how the vast economic powerhouses of big oil use their resources in attempts to influence political decision-making on both local and global levels (see Klein, 2014).

Finally, we argue that drawing on Goffman's (1959) frontstage-backstage analogy could provide fruitful insights to other topics related to corporate responsibility communication, such as the recently much debated issue of corporate taxation and tax avoidance. For instance, the case study presented by Ylönen and Laine (2015) provides an illustrating discussion of a situation, in which in the frontstage the case company emphasized high ethical standards, transparency and accountability in relation to all its activities, while simultaneously in the backstage it was engaging in aggressive tax avoidance schemes, which it clearly wished to remain hidden (see also Preuss, 2012).

Like all studies, ours is subject to some limitations and leads to avenues for future research. We investigate sustainability reporting practices for one single industry in a restricted time period (2004-2006); hence, the extent to which we can generalize our results to other cases or time periods cannot be determined. Focusing on the 2004-2006 period of political debate over drilling in ANWR also might narrow the breadth of insight we could gain from a more extended analysis of ANWR. Our analysis of post-2006 political interest in ANWR shows, however, that the political and corporate will to engage in extensive efforts to open ANWR to drilling seemed to wane after 2006. Without having a specific, significant piece of legislation to anchor our empirical analysis 
on political contributions, extending the examination to later time periods would require too much speculation. Finally, we acknowledge that PAC contributions do not solely drive or reflect corporate political strategies and activities; while PACs help gain access, other omitted factors may have influenced the politics and outcome of the ANWR Bill.

Because Goffman's self-presentation framework takes also into account interactions with the audience in the management of impressions, a dialogue with frontstage and backstage stakeholders such as corporate managers/executives, government officials, federal candidates and possibly NGOs could provide relevant insights on the possible interactions both between them and within the mechanics of corporate political strategy processes, and as such offers interesting research opportunities into the complex web of mechanisms, influences and motivations underlying sustainability reporting. Further work could for instance draw on Goffman's (1959) notion regarding how instead of a single frontstage there might be several simultaneous stages on which an actor needs to go and perform in a particular social role. This kind of a situation could well a describe an organization, which may need to perform in front of several stakeholder groups, say private investors, regulatory inspectors and environmental NGOs, each of which has a particular set of expectations on the organization. Although the performance on different frontstages may differ in emphasis, the actor nonetheless needs to maintain some coherence between them. We thus posit that Goffman's framework continues to have potential for further work regarding corporate sustainability talk and related action. 


\section{REFERENCES}

Abdelrehim, N., Maltby, J., and Toms, S. (2015). Narrative reporting and crises: British Petroleum and Shell, 1950-1958. Accounting History 20(2), 138-157.

Adams, C.A. (2004). The ethical, social and environmental reporting-performance portrayal gap. Accounting, Auditing and Accountability Journal 17(5), 731-757.

Allen, M.W., and Caillouet, R.H. (1994). Legitimation endeavors: Impression management strategies used by an organization in crisis. Communication Monographs 61(1), 44-62.

Apostol, O.M. (2015). A project for Romania? The role of the civil society's counteraccounts in facilitating democratic change in society. Accounting, Auditing and Accountability Journal 28(2): 210-241.

Aras, G., and Crowther, D. (2008). Corporate sustainability reporting: A study in disingenuity? Journal of Business Ethics 87(S1), 279-288.

Arena, C., Bozzolan, S., and Michelon, G. (2015). Environmental reporting: Transparency to stakeholders or stakeholder manipulation? An analysis of disclosure tone and the role of the board of directors. Corporate Social Responsibility and Environmental Management 22(6), 346-361.

Arenas, D., Lozano, J.M., and Albareda, L. (2009). The role of NGOs in CSR: Mutual perceptions among stakeholders. Journal of Business Ethics 88, 175-107.

Arctic Circle. (2009). The Arctic National Wildlife Refuge: A special report. Available at http://arcticcircle.uconn.edu/ANWR/anwrindex.html.

Ashforth, B. and Gibbs, B. (1990). The double-edged sword of organizational legitimation. Organization Science 1(2), 177-194.

Atlas.ti (2004). Atlas.ti 5.0 user's guide and reference. Berlin: Thomas Muhr Scientific Software Development.

Bansal, P., and Clelland, I. (2004). Talking trash: Legitimacy, impression management, and unsystematic risk in the context of the natural environment. The Academy of Management Journal 47(1), 93-103.

Bansal, P., and Hoffman, A. J. (2012). The Oxford Handbook of Business and the Natural Environment. Oxford: Oxford University Press.

Bansal, P., and G. Kistruck. (2006). Seeing Is (Not) Believing: Managing the impressions of the firm's commitment to the natural environment. Journal of Business Ethics 67(2), 165-180.

Bebbington, J., Larrinaga, C., and Moneva, J. M. (2008). Corporate social reporting and reputation risk management. Accounting, Auditing and Accountability Journal $21(3), 337-361$.

Bebbington, J., and Thomson, I. (2013). Sustainable development, management and accounting: Boundary crossing. Management Accounting Research 24(4): 277283.

Bebbington, J., Unerman, J., and O'Dwyer, B. (2014). Sustainability Accounting and Accountability. New York: Routledge.

Beelitz, A. and Merkl-Davies, D.M. (2012). Using discourse to restore organisational legitimacy: 'CEO-speak' after an incident in a German nuclear power plant. Journal of Business Ethics 108(1), 101-120. 
Bell, J., and Lundblad, H. (2011). A comparison of Exxonmobil's sustainability reporting to outcomes. Journal of Applied Business and Economics 12(1), 17-29.

Boiral, O. (2016). Accounting for the Unaccountable: Biodiversity Reporting and Impression Management. Journal of Business Ethics, 135(4), 751-768.

Boiral, O. (2013). Sustainability reports as simulacra? A counter-account of A and A+ GRI reports. Accounting, Auditing and Accountability Journal 26(7), 1036-1071.

Bozzolan, S., Cho, C.H., and Michelon, G. (2015), Impression management and organizational audiences: The Fiat Group case. Journal of Business Ethics 126, 143-165.

Brennan, N.M. and Merkl-Davies, D. (2013). Accounting Narratives and Impression Management. In Lisa Jack, Jane Davison, Russell Craig (eds.). The Routledge Companion to Accounting Communication. Routledge, Oxon.

Brennan, N.M., Merkl-Davies, D.M., and Beelitz, A. (2013). Dialogism in corporate social responsibility communications: Conceptualising verbal interaction between organisations and their audiences. Journal of Business Ethics 115(4), 665-679.

Bryman, A., and Bell, E. (2015). Business research methods. $4^{\text {th }}$ edition. New York: Oxford University Press.

Buhr, N., Gray, R., and Milne, M. (2014). Histories, rationales, voluntary standards and future prospects for sustainability reporting. In J. Bebbington, J. Unerman and B. O'Dwyer (Eds.), Sustainability Accounting and Accountability, 2nd edition (pp. 51-71). New York: Routledge.

Burger, J. (2001). Adequate science: Alaska's Arctic refuge. Conservation Biology 15(2), 539.

Center for Responsive Politics. (2010, 2016). Available at http://www.opensecrets.org

Center for Responsive Politics. (2005). Boiling oil: The money behind the debate over drilling in ANWR. Money in Politics Alert 8(7), March 18.

Chen, J.C., C.H. Cho, and D M. Patten. 2014. Initiating Disclosure of Environmental Liability Information: An Empirical Analysis of Firm Choice. Journal of Business Ethics 125(4): 681-692.

Cheney, G. (1992). The corporate person (re)presents itself. In E. Toth \& R. Heath (Eds.), Rhetorical and critical approaches to public relations. Hillsdale, NJ: Lawrence Erlbaum Associates.

Chevron. (2004). Corporate responsibility report. Available at: http://www.corporateregister.com

Cho, C.H. (2007). The relationship between business and government: An examination of corporate political action committees (PACs) in the Energy and Natural Resources sector. In M.W. Wilcox and T.O. Mohan (Eds.), Contemporary Issues in Business Ethics (pp. 119-133). New York: Nova Science Publishers Inc.

Cho, C. H. (2009). Legitimation strategies used in response to environmental disaster: A French case study of Total S.A.'s Erika and AZF incidents. European Accounting Review 18(1), 33-62.

Cho, C.H., Chen, J.C., and Roberts, R.W. (2008). The politics of environmental disclosure regulation in the chemical and petroleum industries: Evidence from the Emergency Planning and Community Right-to-Know Act of 1986. Critical Perspectives on Accounting 19(4), 450-465. 
Cho, C.H., Patten, D.M., and Roberts, R.W. (2006). Corporate political strategy: An examination of the relation between political expenditures, environmental performance, and environmental disclosure. Journal of Business Ethics 67(2), 139-154.

Cho, C.H., and Roberts, R. (2010). Environmental reporting on the internet by America's Toxic 100: Legitimacy and self-presentation. International Journal of Accounting Information Systems 11(1), 1-16.

Cho, C.H., Laine, M., Roberts, R.W., and Rodrigue, M. (2015). Organized hypocrisy, organizational façades, and sustainability reporting. Accounting, Organizations and Society 40, 78-94.

Clarkson, P.M., Li, Y., Richardson, G.D., and Vasvari F.P. (2008). Revisiting the relation between environmental performance and environmental disclosure: An empirical analysis. Accounting, Organizations and Society 33(4-5), 303-327.

Collinson, D. L. (1999). 'Surviving the rigs': Safety and surveillance on North Sea oil installations. Organization studies 20(4), 579-600.

ConocoPhillips. (2004). Sustainable development report. Available at: http://www.corporateregister.com.

Cooper, S. and Slack, R. (2015). Reporting practice, impression management and company performance: A longitudinal and comparative analysis of water leakage disclosure. Accounting and Business Research 45(6-7), 801-840.

Cormier, D., Gordon, I., and Magnan, M. (2004). Corporate environmental disclosure: Contrasting management's perceptions with reality. Journal of Business Ethics 49(2), 143-165.

Corn, M., Ratner, M., and Alexander, K. (2015). Arctic National Wildlife Refuge (ANWR): A Primer for the $114^{\text {th }}$ Congress. CRS Report, March 17, 2015. Congressional Research Service.

Criado-Jiménez, I., Fernández-Chulián, M., Husillos-Carqués, J., and LarrinagaGonzález, C. (2008). Compliance with Mandatory Environmental Reporting in Financial Statements: The Case of Spain (2001-2003). Journal of Business Ethics $79,245-262$.

Deegan, C. (2014). An overview of legitimacy theory as applied within the social and environmental accounting literature. In J. Bebbington, J. Unerman, and B. O'Dwyer (Eds.), Sustainability Accounting and Accountability, $2^{\text {nd }}$ edition (pp. 248-272). New York: Routledge.

Dhaliwal, D. S., Radhakrishnan, S., Tsang, A., and Yang, Y. G. (2012). Nonfinancial disclosure and analyst forecast accuracy: International evidence on corporate social responsibility disclosure. The Accounting Review 87(3), 723-759.

Doh, J.P., and Guay, T.R. (2006). Corporate social responsibility, public policy, and NGO activism in Europe and the United States: An institutional-stakeholder perspective. Journal of Management Studies 43(1), 47-73.

Dowling, J., and Pfeffer, J. (1975). Organizational legitimacy: Social values and organizational behaviour. Pacific Sociological Review 18(1), 122-136.

Du, S., and Vieira Jr, E.T. (2012). Striving for legitimacy through corporate social responsibility: Insights from oil companies. Journal of Business Ethics, 110(4), 413-427. 
Eismeier, T.J., and Pollock, P.H. (1988). Business, Money and the Rise of Corporate PACs in American Elections. New York: Quorum Books.

Elsbach, K.D., and Sutton, R.I. (1992). Acquiring organizational legitimacy through illegitimate actions: A marriage of institutional and impression management theories. The Academy of Management Journal 35(4), 699-738.

ExxonMobil. (2003). Corporate citizenship report. Available at: http://www.corporateregister.com

ExxonMobil. (2005). Corporate citizenship report. Available at: http://www.corporateregister.com

Federal Election Commission (2010). Available at http://www.fec.gov. Accessed on 11 May 2010.

Global Reporting Initiative (GRI). (2002). Sustainability reporting guidelines. Boston, USA: GRI.

Goffman, E. (1959). The presentation of self in everyday life. New York: Doubleday.

Grafton, J. Lillis, A.M., and Mahama, H. (2011). Mixed methods research in accounting. Qualitative Research in Accounting and Management 8(1), 5-21.

Gray R., Adams, C.A., and Owen, D. (2014). Accountability, Social Responsibility and Sustainability. Accounting for Society and the Environment. Harlow, UK: Pearson.

Gray, R., Owen, D., and Adams, C.A. (2009). Some theories for social accounting?: A review essay and a tentative pedagogic categorisation of theorisations around social accounting Advances in Environmental Accounting and Management 4, 1 54.

Halliburton. (2003). Corporate social responsibility report. Available at: http://www.corporateregister.com.

Higgins, C., and Walker, R. (2012). Ethos, logos, pathos: Strategies of persuasion in social/environmental reports. Accounting Forum 36(3), 194-208.

Holder-Webb, L., and Cohen, J. (2012). The cut and paste society: Isomorphism in codes of ethics. Journal of Business Ethics 107(4), 485-509.

Hooghiemstra, R. (2000). Corporate communication and impression management - New perspectives why companies engage in corporate social reporting. Journal of Business Ethics 27(1), 55-68.

Jeacle, I (2014). "And the BAFTA goes to [...]": The assurance role of the auditor in the film awards ceremony. Accounting, Auditing and Accountability Journal 27(5), $778-808$.

Jeacle, I. (2008). Beyond the boring grey: The construction of the colourful accountant. Critical Perspectives on Accounting 19(8), 1296-1320.

Klein, N. (2014). This Changes Everything: Capitalism vs the Climate. Simon and Schuster, New York.

Koch Industries Inc. (2003). Environmental, health and safety progress report. Available at: http://www.corporateregister.com.

Laine M. (2010). Towards sustaining status quo: Business talk of sustainability in Finnish corporate disclosures 1987-2005. European Accounting Review 19(2), 247-274.

Langley, A. (1999). Strategies for theorizing from process data. The Academy of Management Review 24(4), 691-710. 
League of Conservation Voters. (2005). National Environmental Scorecard. Washington, DC.

League of Conservation Voters. (2006) National Environmental Scorecard. Washington, DC.

Leary, M.R. and Kowalski, R.M. (1990). Impression management: A literature review and two-component model. Psychological Bulletin 107(1), 34-47.

Luque-Vilchez, M. and Larrinaga, C. (2016). Reporting models do not translate well : Failing to regulate CSR reporting in Spain. Social and Environmental Accountability Journal 36(1), 56-75.

Madsen, P.M. and Rodgers, Z.J. (2015). Looking good by doing good: The antecedents and consequences of stakeholder attention to corporate disaster relief. Strategic Management Journal 36, 776-794.

Malina, M.A., Nørreklit, H.S.O., and Selto, F.H. (2011). Lessons learned: Advantages and disadvantages of mixed method research. Qualitative Research in Accounting and Management 8(1), 59-71.

Mallin, C., Michelon, G., and Raggi, D. (2013). Monitoring intensity and stakeholders' orientation: How does governance affect social and environmental disclosure? Journal of Business Ethics 114(1), 29-43.

Marathon. (2004). Living our values. Available at: http://www.corporateregister.com.

Matejek, S., and Gössling, T. (2014). Beyond legitimacy: A case study in BP's "green lashing". Journal of Business Ethics 120(4), 571-584.

McCormick, D.W. (2007). Dramaturgical analysis of organizational change and conflict. Journal of organizational change management 20(5), 685-699.

McDonald, J., and Moffitt, R. (1980). The uses of Tobit analysis. Review of Economics and Statistics 62(2), 318-321.

Merkl-Davies, D.M. and Brennan, N.M. (2011). A conceptual framework of impression management: New insights from psychology, sociology and critical perspectives. Accounting and Business Research 41(5), 415-437.

Merkl-Davies, D.M., and Brennan, N.M. (2007). Discretionary disclosure strategies in corporate narratives: Incremental information or impression management? Journal of Accounting Literature 26, 116-194.

Michelon, G. (2012). Impression management and legitimacy strategies: The BP case. Financial Reporting 4, 35-64.

Michelon, G., Pilonato, S., and Ricceri, F. (2015). CSR reporting practices and the quality of disclosure: An empirical analysis. Critical Perspectives on Accounting 33, 59-78.

Miles, M.B., and Huberman, A.M. (1994). Qualitative data analysis: An expanded sourcebook. Thousand Oaks: Sage Publications.

Milne, M. J., and Gray, R. (2013). W(h)ither ecology? The triple bottom line, the Global Reporting Initiative and corporate sustainability reporting. Journal of Business Ethics 118(1), 13-29.

Milne, M.J. and Patten, D.M. (2002). Securing organizational legitimacy. An experimental decision case examining the impact of environmental disclosures. Accounting, Auditing and Accountability Journal 15(3), 372-405. 
Milne, M.J., Tregidga, H. and Walton, S. (2009). Words not actions! The ideological role of sustainable development reporting. Accounting, Auditing and Accountability Journal, 22(8), 1211-1257.

Mitchell, R.K., Agle, B.R., and Wood, D.J. (1997). Toward a theory of stakeholder identification and salience: Defining the principle of who and what really counts. Academy of Management Review 22(4), 853-886.

Moneva, J. M., Archel, P., and Correa, C. (2006). GRI and the camouflaging of corporate unsustainability, Accounting Forum 30(2), 121-137.

Neu, D., Warsame, H., and Pedwell, K. (1998). Managing public impressions: Environmental disclosures in annual reports. Accounting, Organizations and Society 23(3), 265-282.

Occidental Petroleum Corporation. (2003a). Health, environment and safety annual report. Available at: http://www.corporateregister.com.

Occidental Petroleum Corporation. (2003b). Social responsibility report. Available at: http://www.corporateregister.com.

Ogden, S. and Clarke, J. (2005). Customer disclosures, impression management and the construction of legitimacy: Corporate reports in the UK privatised water industry. Accounting, Auditing \& Accountability Journal 18(3), 313-345.

O'Dwyer, B. (2004). Qualitative data analysis: Illuminating a process for transforming a 'messy' but 'attractive' 'nuisance'. In C. Humphrey and B. Lee (Eds.), The Real Life Guide to Accounting Research: A Behind-The-Scene View of Using Qualitative Research Methods (pp. 391-407). London: Elsevier.

Patten, D.M. (1992). Intra-industry environmental disclosures in response to the Alaskan oil spill: A note on legitimacy theory. Accounting, Organizations and Society 17(5), 471-475.

Patten, D.M. (2002). The relation between environmental performance and environmental disclosure: a research note. Accounting, Organizations and Society 27(8), 763-773.

Podesta, J., and Boots, M. (2015). President Obama calls on Congress to protect Arctic Refuge as wilderness. The White House Blog. Available at https://www.whitehouse.gov/blog/2015/01/25/president-obama-calls-congressprotect-arctic-refuge-wilderness.

Preuss, L. (2012). Responsibility in Paradise? The adoption of CSR tools by companies domiciled in tax havens. Journal of Business Ethics 110(1), 1-14.

Reid, E.M., and Toffel, M.W. (2009). Responding to public and private politics: Corporate disclosure of climate change strategies. Strategic Management Journal 30(11), 1157-1178.

Rinaldi, L., Unerman, J., and Tilt, C.A. (2014). The role of stakeholder engagement and dialogue within the sustainability accounting and reporting process. In $\mathrm{J}$.

Bebbington, J. Unerman, and B. O'Dwyer (Eds.), Sustainability Accounting and Accountability, $2^{\text {nd }}$ edition (pp. 86-107). New York: Routledge.

Roberts, R.W., Dwyer, P.D., and Sweeney, J.T. (2003). Political strategies used by the U.S. public accounting profession during auditor liability reform: The case of the Private Securities Litigation Reform Act of 1995. Journal of Accounting and Public Policy 22(5), 433-457. 
Rodrigue, M. (2014). Contrasting realities: corporate environmental disclosure and stakeholder-released information. Accounting, Auditing and Accountability Journal 27(1), 119-149.

Rodrigue, M., Magnan, M., and Cho, C.H. (2013). Is environmental governance substantive or symbolic? An empirical investigation. Journal of Business Ethics 114(1), 107-129.

Ross, D.A.R. (2007). Backstage with the knowledge boys and girls: Goffman and distributed agency in an organic online community. Organization Studies 28(3), 307-325.

Rost, K., and Ehrmann, T. (forthcoming). Reporting biases in empirical management research: The example of win-win corporate social responsibility. Business and Society. DOI: $10.1177 / 0007650315572858$

Sandberg, M., and Holmlund, M. (2015). Impression management tactics in sustainability reporting. Social Responsibility Journal 11(4), 677-689.

Scherer, A.G., and Palazzo, G. (2011). The new political role of business in a globalized world: A review of a new perspective on CSR and its implications for the firm, governance, and democracy. Journal of Management Studies 48(4), 899-931.

Shogren, E. (2005). For 30 years, a political battle over oil and ANWR. All things considered. National Public Radio, November 10.

Smith, M.A. (2000). American business and political power. Chicago: The University of Chicago Press.

Solomon, J.F., Solomon, A., Joseph, N.L., and Norton, S.D. (2013). Impression management, myth creation and fabrication in private social and environmental reporting: Insights from Erving Goffman. Accounting, Organizations and Society 38, 195-213.

Spence, C., Husillos, J., and Correa-Ruiz, C. (2010). Cargo cult science and the death of politics: A critical review of social and environmental accounting research. Critical Perspectives on Accounting 21(1): 76-89.

Stolberg, S. (2008). Bush calls for end on offshore drilling. The New York Times, June 19.

Talbot, D., and Boiral, O. (2015). Strategies for climate change and impression management: A case Study among Canada's large industrial emitters. Journal of Business Ethics 132(2), 329-346.

Talbot, D., and Boiral, O. (forthcoming). GHG Reporting and impression management: An assessment of sustainability reports from the energy sector. Journal of Business Ethics. doi:10.1007/s10551-015-2979-4

Tata, J., and Prasad, S. (2015). CSR communication: An impression management perspective. Journal of Business Ethics 132(4), 765-778.

Thornburg, S.W., and Roberts, R.W. (2008). Money, politics and the regulation of public accounting services: Evidence from the Sarbanes-Oxley Act of 2002. Accounting, Organizations and Society 31(2-3), 229-248.

THOMAS. (2009). The Library of Congress. Available at http://thomas.loc.gov.

Thomson, I., Russell, S., and Dey, C. (2015). Activism, arenas and accounts in conflicts over tobacco control. Accounting, Auditing and Accountability Journal 28(5), 809-845. 
Tregidga, H., Milne, M., and Kearins, K. (2014). (Re)presenting 'sustainable organizations'. Accounting, Organizations and Society 39(6), 477-494.

Tregidga, H. and Milne, M.J. (2006). From sustainable management to sustainable development: a longitudinal analysis of a leading New Zealand environmental reporter. Business Strategy and the Environment 15, 219-41.

Unerman, J., and Chapman, C. (2014). Academic contributions to enhancing accounting for sustainable development. Accounting, Organizations and Society 39(6): 385394.

Unerman, J. and Zappettini, F. (2014). Incorporating materiality considerations into analyses of absence from sustainability reporting. Social and Environmental Accountability Journal 34(3), 172-186.

U.S. $96^{\text {th }}$ Congress. (2009). Alaska National Interest Lands Conservation Act. Public Law 96-487. Available at http://alaska.fws.gov/asm/anilca/toc.html.

U.S. Department of Energy. (2008). Analysis of crude oil production in the Arctic National Wildlife Refuge. Energy Information Administration, SR/OIAF/2008-03. Washington, DC.

U.S. Department of Interior. (2015). Obama administration moves to protect Arctic National Wildlife Refuge. Available at https://www.doi.gov/news/pressreleases/obama-administration-moves-to-protectarctic-national-wildlife-refuge.

U.S. House of Representatives. (2009). Office of the Clerk. Available at http://clerk.house.gov.

van Halderen, M.D., Bhatt, M., Berens, G.A., Brown, T.J., \& Van Riel, C.B. (2016). Managing impressions in the face of rising stakeholder pressures: Examining oil companies' shifting stances in the Climate Change debate. Journal of Business Ethics 133(3), 567-582.

Waller, D. (2001). Some shaky figures on ANWR drilling. Time, August 13.

White, R., and Hanson, D. (2002). Corporate self, corporate reputation and corporate annual reports: Re-enrolling Goffman. Scandinavian Journal of Management 18(3), 285-301.

Windsheid, L., Bowes-Sperry, L., and Morner, M. (forthcoming). Managing organizational gender diversity images: A content analysis of German corporate websites. Journal of Business Ethics. doi:10.1007/s10551-016-3292-6

Ylönen, M., and Laine, M. (2015). For logistical reasons only? A case study of tax planning and corporate social responsibility reporting. Critical Perspectives on Accounting 33, 5-23.

Young, T.R., and Massey, G. (1978). The dramaturgical society: A macro-analytic approach to dramaturgical analysis. Qualitative Sociology 1(2), 78-98. 
Table 1 - Panel A

Data summary

Political action committees of U.S. oil and gas firms

\begin{tabular}{|c|c|c|c|}
\hline Name & $\begin{array}{c}\text { PAC Contributions } \\
\text { Total }\end{array}$ & $\begin{array}{c}\text { PAC Contributions } \\
\text { Democrats }\end{array}$ & $\begin{array}{c}\text { PAC Contributions } \\
\text { Republicans }\end{array}$ \\
\hline Chevron & $\$ 458,950$ & $\$ 60,200$ & $\$ 398,750$ \\
\hline ConocoPhilips & $\$ 371,500$ & $\$ 31,000$ & $\$ 340,500$ \\
\hline ExxonMobil & $\$ 957,500$ & $\$ 58,350$ & $\$ 899,150$ \\
\hline Halliburton & $\$ 212,500$ & $\$ 21,500$ & $\$ 191,000$ \\
\hline Koch & $\$ 1,048,500$ & $\$ 225,000$ & $\$ 823,500$ \\
\hline Marathon & $\$ 207,450$ & $\$ 53,500$ & $\$ 153,950$ \\
\hline Occidental & $\$ 520,000$ & $\$ 97,500$ & $\$ 422,500$ \\
\hline Total & $\$ 3,776,400$ & $\$ 547,050$ & $\$ 3,229,350$ \\
\hline
\end{tabular}


Table 1 - Panel B

Data summary

$109^{\text {th }}$ Congress House of Representatives $(2004 / 2006$ election cycles)

Data summary on House members and vote

Party affiliation

197 Democrats

228 Republicans 1 Independent

Vote for ANWR Bill

27

198

0

Vote against ANWR Bill

170

30

1

Data summary on House members and Natural Resources Committee membership

House Committee on Natural

Committee

Committee

Resources

members

non-members

Membership during the 2004 and

2006 election cycles

59

Total PAC dollar contributions received from firms operating in the U.S. oil and gas industry

Mean PAC dollar contributions received per member from firms operating in the U.S. oil and gas industry $\$ 13,408$

$\$ 8,134 \quad(p<.05)^{*}$

* Significance level is based on a two-tailed test. 
Table 2

Data summary

$109^{\text {th }}$ Congress House Committee on Natural Resources (2004/2006 election cycles)

\section{Panel A}

Data summary on House Committee on Natural Resources based on party affiliation

\section{Party affiliation}

Number of members

-who voted for ANWR Bill

-who voted against ANWR Bill
Democratic

27

6

21

13
Republican

32

30

2

Number of members who received PAC contributions from firms operating in the U.S. oil and gas industry

Total PAC dollar contributions received from firms operating in the U.S. oil and gas industry

Mean PAC dollar contributions received per member from firms operating in the U.S. oil and gas industry $\$ 5,170$ 78.30 $\$ 20,359$

$(p=.001)^{* *}$

LCV voting score $(p=.001)^{* *}$

\section{Panel B}

Data summary on House Committee on Natural Resources based on vote

\section{Vote on the ANWR Bill}

Number of members

-Democrat

-Republican
Against

23

21

2

7

$\$ 28,100$

Number of members who received PAC contributions from firms operating in the U.S. oil and gas industry

Total PAC dollar contributions received from firms operating in the U.S. oil and gas industry

Mean PAC dollar contributions received per member from firms operating in the U.S. oil and gas industry

${ }^{* *}$ Significance levels are based on two-tailed tests. 


\section{Table 3}

Tobit results for tests of pooled cross-sectional relation between PAC contribution dollars made by firms operating in the U.S. oil and gas industry during the 2004 and 2006 election cycles and the $109^{\text {th }}$ U.S. Congress House Committee on Natural Resources membership, controlling for party affiliation and LCV environmental voting rating. The Tobit regression model is: OIL_GAS_PAC $=a_{1}+$ b 1 COM_RESOURCES + b b $_{2}$ PARTY + b $_{3} L C V$.

Model explanatory power

Number of observations

Pseudo Chi-Square statistic

Pseudo R-squared

Parameter estimates

\begin{tabular}{lcccc}
\hline Variable & $\begin{array}{c}\text { Predicted } \\
\text { sign }\end{array}$ & $\begin{array}{c}\text { Parameter } \\
\text { estimate }\end{array}$ & t-stat & $\begin{array}{c}\text { Significance } \\
(\mathbf{p}-\mathbf{v a l u e})^{*}\end{array}$ \\
\hline COM_RESOURCES & $(+)$ & 3954.75 & 1.773 & 0.038 \\
PARTY & $(+/-)$ & -3579.13 & -1.207 & 0.227 \\
LCV & $(+/-)$ & -386.22 & -9.059 & 0.000 \\
Intercept & None & 22531.95 & 6.492 & 0.000 \\
& & & \\
Dependent variable = OIL_GAS_PAC & & & \\
\hline
\end{tabular}

* Significance levels are based on a one-tailed test for the COM_RESOURCES variables and two-tailed for the PARTY and LCV variables.

OIL_GAS_PAC = PAC dollar contributions made by firms in the U.S. oil and gas industry to members of the $109^{\text {th }}$ U.S. House of Representatives during the 2004 and 2006 election cycles;

COM_RESOURCES = Dummy variable, 1 if the Representative is a member of the House Resources Committee under the U.S. $109^{\text {th }}$ Congress, 0 otherwise;

PARTY = Dummy variable, 1 if the Representative is affiliated with the Republican party, 0 otherwise;

$\mathrm{LCV} \quad=$ Representative's environmental voting record score assessed by the League of Conservation Voters. 


\section{Table 4}

Binary logistic regression results for tests of pooled cross-sectional relation between the $109^{\text {th }}$ Congress House members' vote on the ANRW Bill (House Bill H.R. 5429) and PAC contribution dollars made by firms operating in the U.S. oil and gas industry during the 2004 and 2006 election cycles, controlling for party affiliation and LCV environmental voting rating. The binary logistic regression model is: VOTE $=\mathbf{a}_{1}+$ b1OIL_GAS_PAC + b $_{2}$ PARTY + b $_{3} L C V$.

Model explanatory power

Number of observations

-2 Log Likelihood

Hosmer-Lemeshow Chi-squared

Sig. of Chi-squared statistic

0.760

Nagelkerke R-squared

Parameter estimates

\begin{tabular}{lccccc}
\hline Variable & $\begin{array}{c}\text { Predicted } \\
\text { sign }\end{array}$ & $\begin{array}{c}\text { Parameter } \\
\text { estimate }\end{array}$ & Wald & $\begin{array}{c}\text { Significance } \\
(\mathbf{p}-\text {-value) }\end{array}$ & Odds ratio \\
\hline OIL_GAS_PAC & $(+)$ & 0.112 & 2.337 & 0.063 & 0.073 \\
PARTY & $(+/-)$ & 3.783 & 15.853 & 0.000 & 0.950 \\
LCV & $(+/-)$ & -0.188 & 48.692 & 0.000 & 0.027 \\
Intercept & None & 10.120 & 36.615 & 0.000 & 1.673 \\
& & & & & \\
Dependent variable=VOTE & & & & & \\
\hline
\end{tabular}

* Significance levels are based on a one-tailed test for the OIL_GAS_PAC variable and twotailed for the PARTY and LCV variables.

VOTE = Dummy variable, 1 if the Representative voted for House Bill H.R. 5429, 0 otherwise;

OIL_GAS_PAC = Natural log of PAC dollar contributions made by firms in the U.S. oil and gas industry to members of the $109^{\text {th }}$ U.S. House of Representatives during the 2004 and 2006 election cycles;

PARTY = Dummy variable, 1 if the Representative is affiliated with the Republican party, 0 otherwise;

$\mathrm{LCV} \quad=$ Representative's environmental voting record score assessed by the League of Conservation Voters. 


\section{Appendix}

Timeline for Key Events in the Arctic National Wildlife Refuge Drilling Debate

\begin{tabular}{|c|c|c|c|c|c|}
\hline $\begin{array}{l}\text { ANWR is declared } \\
\text { federal protected } \\
\text { area under } \\
\text { President } \\
\text { Eisenhower's } \\
\text { administration. }\end{array}$ & $\begin{array}{l}\text { Drilling in " } 1002 \\
\text { area" of ANWR } \\
\text { becomes subject to } \\
\text { much debate and } \\
\text { controversy in U.S. } \\
\text { media and politics. }\end{array}$ & $\begin{array}{l}\text { ANWR secured by } \\
\text { the Alaska National } \\
\text { Interest Lands } \\
\text { Conservation Act of } \\
1980 \text { to prevent } \\
\text { drilling activity. }\end{array}$ & $\begin{array}{c}\text { Political activities } \\
\text { advocating } \\
\text { drilling in ANWR } \\
\text { led to H.R. } 5429 \\
\text { legislative actions } \\
\text { including voting. }\end{array}$ & $\begin{array}{l}\text { U.S. Congress } \\
\text { rejects several } \\
\text { proposed actions } \\
\text { that contained } \\
\text { ANWR } \\
\text { provisions. }\end{array}$ & $\begin{array}{c}\text { President Obama } \\
\text { asks Congress to } \\
\text { designate ANWR } \\
\text { as wilderness to } \\
\text { prevent drilling } \\
\text { permanently. }\end{array}$ \\
\hline$\downarrow$ & $\downarrow$ & 1980 & $\downarrow$ & $\downarrow$ & $2015-2016$ \\
\hline
\end{tabular}

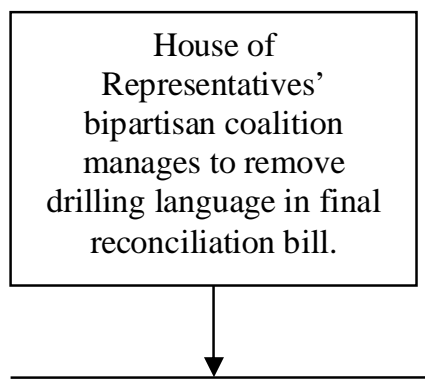

March 2005

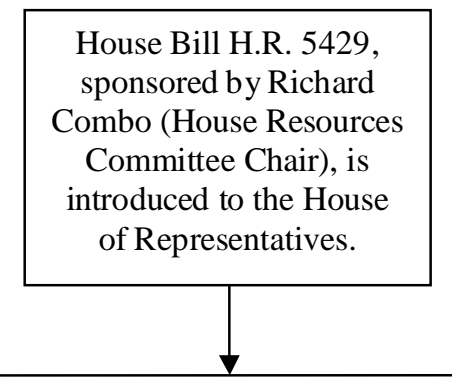

May 19, 2006

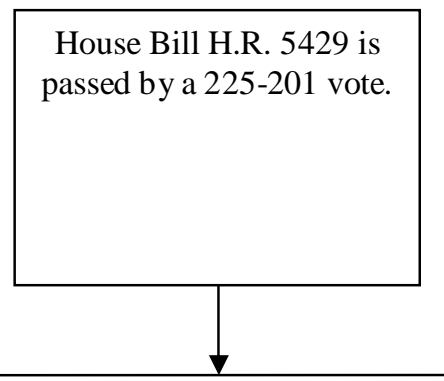

May 25, 2006

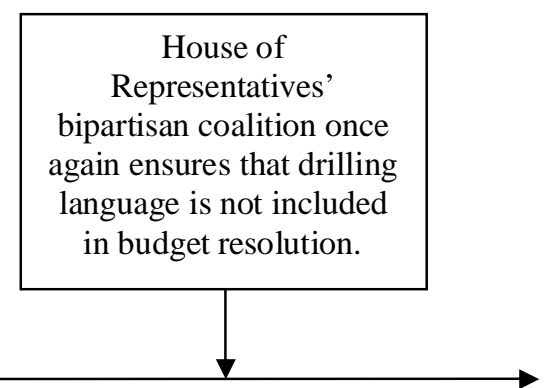

Summer 2006 